\title{
Limnology and plankton diversity of salt lakes from Transylvanian Basin (Romania): A review
}

\author{
Mircea ALEXE, ${ }^{1}$ Gheorghe ȘERBAN,${ }^{*}$ Andreea BARICZ, ${ }^{2}$ Adrian-Ștefan ANDREI,${ }^{3,4}$ Adorján CRISTEA,${ }^{4}$ \\ Karina P. BATTES, ${ }^{5}$ Mirela CÎMPEAN, ${ }^{5}$ Laura MOMEU, ${ }^{5}$ Vasile MUNTEAN,${ }^{4}$ Sebastian A. PORAV,${ }^{6}$ Horia L. BANCIU ${ }^{4,7}$
}

${ }^{1}$ Department of Physical and Technical Geography, Faculty of Geography, Babeş-Bolyai University, 5-7 Clinicilor Str., 400006 Cluj-Napoca, Romania; ${ }^{2}$ National Institute of Research and Development for Biological Sciences (NIRDBS), Institute of Biological Research, 48 Republicii Str., 400015 Cluj-Napoca, Romania; ${ }^{3}$ Department of Aquatic Microbial Ecology, Institute of Hydrobiology, Biology Center of the Academy of Sciences of the Czech Republic, Na Sádkách 7, 37005 České Budějovice, Czech Republic; ${ }^{4}$ Department of Molecular Biology and Biotechnology, Faculty of Biology and Geology, Babeş-Bolyai University, 5-7 Clinicilor Str., 400006 Cluj-Napoca, Romania; 5 5Department of Taxonomy and Ecology, Faculty of Biology and Geology, Babeş-Bolyai University, 5-7 Clinicilor Str., 400006 Cluj-Napoca, Romania; ${ }^{6}$ Electron Microscopy Center, Babeş-Bolyai University, 5-7 Clinicilor street, ClujNapoca, Romania; ${ }^{7}$ Center for Systems Biology, Biodiversity, and Bioresources, Babes-Bolyai University, 5-7 Clinicilor Str., 400006 Cluj-Napoca, Romania

*Corresponding author: gheorghe.serban@ubbcluj.ro

\begin{abstract}
In the present work, we review the current knowledge on genesis, limnology and biodiversity of salt lakes distributed around the inner contour of Eastern Carpathian arc (Transylvanian Basin, Central Romania). Transylvanian salt lakes formed on ancient halite $(\mathrm{NaCl})$ deposits following natural processes or quarrying activities. Most of these lakes are located in eastern (Sovata area), southern (Ocna Sibiului), and western (Turda-Cojocna) parts of the Transylvanian Basin, have small surfaces (0.1-4 ha), variable depths $(2-100 \mathrm{~m})$, are hypersaline $(>10 \%$, w/v, total salts, mainly $\mathrm{NaCl})$ and permanently stratified. As consequence of steady salinity/density gradient, heat entrapment below surface layer (i.e., heliothermy) develops in several Transylvanian lakes. The physical and chemical water stratification is mirrored in the partition of plankton diversity. Lakes with less saline (2-10\% salinity) water layers appear to harbor halotolerant representatives of phyto- (e.g., marine native Picochlorum spp. and Synechococcus spp.), zoo(e.g., Moina salina), and bacterioplankton (e.g., Actinobacteria, Verrucomicobia), whereas halophilic plankton communities (e.g., green algae Dunaliella sp., brine shrimp Artemia sp., and members of Halobacteria class) dominate in the oxic surface of hypersaline ( $>10 \%$ salinity) lakes. Molecular approaches (e.g., PCR-DGGE, 16S rRNA gene-based clone libraries, and DNA metabarcoding) showed that the $\mathrm{O}_{2}$-depleted bottom brines of deep meromictic Transylvanian lakes are inhabited by known extremely halophilic anaerobes (e.g. sulfate-reducing Delta-Proteobacteria, fermenting Clostridia, methanogenic and polymer-degrading archaea) in addition to representatives of uncultured/unclassified prokaryotic lineages. Overall, the plankton communities thriving in saline Transylvanian lakes seem to drive full biogeochemical cycling of main elements. However, the trophic interactions (i.e., food web structure and energy flow) as well as impact of human activities and predicted climate changes are yet to be assessed in these unique ecosystems with little or no match to analogous salt lakes worldwide.
\end{abstract}

Key words: Biodiversity; halite; halophilic; hypersaline; meromictic lake; picophytoplankton; zooplankton.

Received: April 2017. Accepted: August 2017.

\section{INTRODUCTION}

Saline environments (i.e., those milieus exceeding sea water salinity of $\sim 3.5 \%$, w/v, total salts) occur worldwide either as terrestrial (e.g., salt marshes, saline soils) or aquatic habitats (e.g., inland saline lakes, deep-sea brines, solar evaporation ponds, etc.) (Hammer, 1986; O’Leary and Glenn, 1994; Oren, 2016). Based on their origin, saline aquatic systems are classified into thalassohaline (derived from sea water) or athalassohaline (i.e., of land origin) (Hammer, 1986). Additionally, inland saline aquatic systems can be classified into pH-neutral (enriched in $\mathrm{Na}^{+}$and $\mathrm{Cl}^{-}$; e.g., Great Salt Lake in Utah, USA, and Dead Sea in the Middle East) (Belovsky et al., 2011; Oren, 2016), alkaline (with elevated $\mathrm{Na}^{+}$and $\mathrm{HCO}_{3}-\mathrm{CO}_{3}{ }^{2}$; e.g., soda lakes in the Siberian steppe or Eastern African Rift Valley) (Sorokin et al., 2015; Deocampo and Renaut, 2016) and acid saline lakes (e.g., the ephemeral sulfaterich brines in SW Australia) (Benison and Bowen, 2015). According to the above classifications, all inland salt lakes in Transylvanian Basin (Central Romania) are pH-neutral, athalassohaline systems (Baricz et al., 2014; 2015). On the contrast to numerous neutral salt lakes investigated to date in North America (Belovsky et al., 2011), Middle East (Makhdoumi-Kakhki et al., 2012; Oren, 2016), Australia (Podell et al., 2013) or Antarctica (Laybourn- 
Parry and Bell, 2014), the limnology and biology of salt lakes in Romania are only scarcely visible in the main stream of scientific literature. Previous works reported on morphometry and limnogeology (Bulgăreanu (1993; 1996), zoo- and phytoplankton diversity (Ionescu et al., 1998), enzymatic activity associated to organic-rich sediments (Muntean et al., 1996) and potential for novel microbial taxa in Romanian salt lakes (Enache et al., 2007). The aim of the present work is to review the current knowledge on the origin, hydromorphological, physicochemical, and biological particularities of most representative salt lakes situated in Transylvanian Basin, with emphasis on recent advancements in the understanding of ecological complexity of these extreme aquatic habitats.

\section{Brief history of salt lakes research in Transylvania}

Salt lakes are distinctive components of the Transylvanian Basin landscape; they have been extensively observed and exploited over time. The physico-chemical peculiarities of salt waters (e.g., heliothermy) and the therapeutic value of organic-rich sediments (or 'sapropels') are most relevant features of Transylvanian salt lakes that led to early capitalization and scientific interest.

The first documented observation of the salt water heating phenomenon took place at the end of $19^{\text {th }}$ Century in a salt basin near Miserey (Besançon, France) where temperature value of $62^{\circ} \mathrm{C}$ was recorded at $1.35 \mathrm{~m}$ depth without any further scientific explanation (Ziegler, 1898, commented by Lang, 1898). Shortly afterwards, von Kalecsinszky (1901) was first to methodically study how brines can store heat as consequence of lens effect of freshwater surface, performing a series of observations and measurements on Ursu Lake (Sovata). He suggested that the thin layer of low-saline or freshwater at the surface of the lakes topping the deeper hypersaline horizon favoured significant increase of temperature at a depth of 1.5-3 m. Following these observations, Ursu and its analogous saline lakes in Sovata were termed as 'wärmeaccumulatoren' ('heat reservoirs', von Kalecsinszky, 1901). According to Sonnenfeld and Hudec (1980), I.A. Maxim conceived the term 'heliothermal' for lakes entrapping a warmer layer between the upper and deeper strata with lower temperature, a phenomenon latter coined 'thermal anomaly' by Touchart (2002).

The curative effects of salt lakes of Transylvania (mainly in Turda, Ocna Sibiului, and Sovata) have been testified since $16^{\text {th }}$ Century by princes, nobles or physicians that invited various acquaintances to heal infertility, skin or rheumatic ailments (Alexe, 2010). During the $19^{\text {th }}$ and $20^{\text {th }}$ Century, respectively, intermittent scientific observations (1820-1896) were followed by systematic surveys on limnology, geochemistry, and morphometry of most if not all Transylvanian salt lakes (Supplementary Tab. S1).

\section{Genesis of salt lakes in the Transylvanian Basin}

The basement of Transylvanian Basin belongs to the Eastern Carpathian type, being composed of crystalline schist and Mid-Cretaceous conglomerates lying at a depth of $4500 \mathrm{~m}$. This area slowly subducted during Late Cretaceous as indicated by the Paleogene and Neogene sediments arranged in continuous succession, which filled up the basin (Sanders et al., 2002). Several genetic phases configured the present-day Transylvanian Basin (Supplementary Fig. S1):

- the phase of Paleogene basin situated inside the Eastern Carpathians arc and bordered by crystalline massifs of Rodna, Preluca, Dealu Mare, Dealu Codrului, the Apuseni Mountains and the Meridional Carpathians, where thick packages of Eocene and Oligocene sandstones were stored (Pop, 2000); during this phase, the northern and western parts of the basin were covered by marine waters, being affected by a gradual descent and an important sedimentation;

- beginning with the Middle Miocene (Badenian), after a tectonic fragmentation, the eruptive chain OaşGutâi-Ţibleş was born, the old intra-Carpathian basin being divided into two compartments: a smaller area in the north (Maramureş Basin) and a larger one in the central part (Transylvanian Plateau); around $14 \mathrm{Ma}$ ago, following the Central Paratethys Sea regression, massive evaporite sediments (mostly halite and gypsum) formed in Transylvanian Basin and Carpathian Foredeep, respectively, in a relatively short geological period (0.2 Ma) (Ciupagea et al., 1970; Báldi, 2006);

- upper Pliocene marks the third phase, with sea level drop and retreat of marine waters to the south-east followed by the subaerial shaping of north and centre sub-basins; sediments (Pliocene) were deposited further on the edges, in conjunction with the areas where the Pliocene sea withdrew (the actual corridor of the Someş, Mureş, and Olt rivers).

The rise of the mountain area triggered the development of diapiric folds on the edges (Praid, Turda, Ocna Dej, Cojocna, Ocna Mureş, Ocna Sibiului) (Pop, 2000).

Due to the geological evolution, the Transylvanian Plateau consists of two relatively concentric areas with distinct geological structure, morphology and spatial organization: quasi-horizontal structures in central area, arched as domes from place to place and a folded structure on the outside (milder on the western and southern and more pronounced on the eastern part), corresponding to the alignments of diapirs (Irimuş, 1998).

Salt lakes are an evolutionary and residual component of salt horizons from the base of sedimentary deposits, which under the pressure of sediments have migrated to the periphery in contact with the mountain area. As a result of migration, numerous salt domes formed and subsequently affected by subaerial agents, thus salt appearing 
on surface (Irimuş, 1998; 2006). The appearance of salt led either to mining since Roman period or the occurrence of surface pseudokarst, resulting in numerous artificial or dissolution lakes (Gâştescu, 1971). All saline lakes presently found in the Transylvanian Basin formed by salt dissolution of underground halite deposits (Har et al., 2010). They are located in Sovata, Ocna Sibiului, Ocna Mureş, Turda, Cojocna, Sic, Ocna Dej, and Jabeniţa areas (Alexe, 2010; Alexe and Şerban, 2014a, 2014b) (Fig. 1).

\section{Limnology of most representative saline lakes}

Nowadays, 41 salt lakes are counted among which 7 lakes (five in Sovata and two in Ocna Sibiului) appeared by natural processes (or 'karstosaline' - a term proposed by Bulgăreanu, 1993; 1996) and the others being situated in ex-underground or surface salt mining areas (manmade or 'anthroposaline' lakes). Generally, Transylvanian salt lakes have small areas but with significant depths (Tabs. 1 and 2) (Alexe, 2010; Şerban et al., 2005; Alexe and Alexe, 2008; Alexe and Şerban, 2014a).

Eleven Transylvanian saline lakes with significant depths $(>-10 \mathrm{~m})$ and salinity $(>30 \%, \mathrm{w} / \mathrm{v}$, total salts, at the bottom layer) developed ideal conditions for permanent density stratification and, therefore, are heliothermal. While the amplitude of this phenomenon remains quite low in most lakes (up to $5^{\circ} \mathrm{C}$ ), in the Ursu Lake (Sovata)

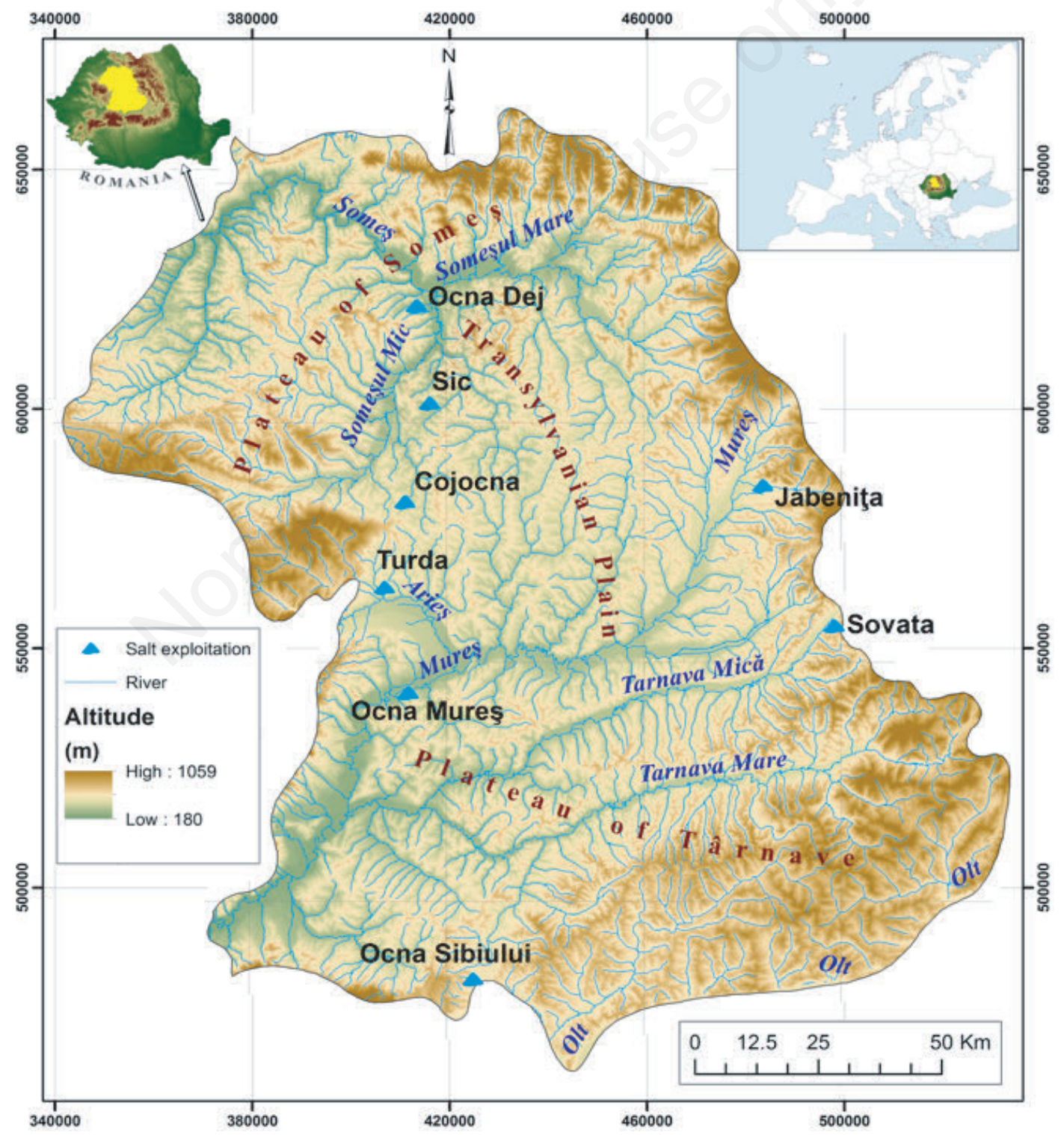

Fig. 1. Locations of salt lakes in the Transylvanian Basin at local (center), Romania (upper left) and Europe scales (upper right). 
the temperature difference between the surface and heliothermal layer (1.5-3 $\mathrm{m} \mathrm{depth})$ is frequently exceeding $12^{\circ} \mathrm{C}$ and may reach up to $25^{\circ} \mathrm{C}$ during summer (Alexe and Șerban, 2006, 2014a, 2014b). Moreover, by its morphometry, Ursu Lake appears as one of the the largest saline heliothermal lakes in the world. Although rarely encountered, heliothermal bodies of water were reported on all continent and climate zones in Asia (e.g., in Siberian and Mongolian steppes) (Sonnenfeld and Hudec, 1980; Egorov, 1993), Africa (Solar Lake, Sinai, Egypt) (Cohen et al., 1977), North America (Hot Lake, WA, USA; Mahoney Lake, BC, Canada) (Zachara et al., 2016; Northcote and Hall, 1983), Antarctica (Ekho Lake, Vestfold Hills) (Bowman et al., 2000), Australia and Pacific Islands (Hudec and Sonnenfeld, 1989).

Brief descriptions of the saliferous Transylvanian areas with best investigated salt lakes are given below.

The basin of Sovata is a combe developed and formed by erosion along the diapiric anticline as a result of the epigenetic sinking processes of the Târnava Mică River and its tributaries in the diapiric folds (Alexe et al., 2006). The most representative lake in Sovata basin is Ursu - or 'Bear' - (4636'15 N; 2505'09 E) (Fig. 2). It appeared following the accelerated dissolution of underground salt deposit that created a huge abruption, causing a landfall. The two nearby rivulets filled up this gap resulting in the present lake (with a contour resembling the shape of a bear fur). Unofficial sources (i.e., not supported by cadastral information) indicated that the lake started to form between 1875 and 1879 (Lengyel, 1898).

In Turda area, the lacustrine complexes (DurgăuValea Sărată, and Băilor complex) are situated in the vicinity of Turda city and lie on the western border of the Transylvanian Basin, in a diapiric area which appears in the open under the form of salt massifs (Alexe, 2010) (Figs. 1 and 2). The two lakes discussed in this review (Ocnei - 'Salt Mine's'; and Rotund - 'Round') are located in the Durgău-Valea Sărată lacustrine complex and exploited for outdoor bathing during warm seasons. Both lakes are fed by rainfall and freshwater springs and main-

Tab. 1. Main features of Transylvanian salt lakes.

\begin{tabular}{|c|c|}
\hline Characteristic & Description \\
\hline Number & - a total number of 41 salt lakes are charted in Transylvanian Basin (Central Romania). \\
\hline Origin & $\begin{array}{l}\text { - formed on the Miocene halite }(\mathrm{NaCl}) \text { deposits dating from Badenian salt crisis event; - most of lakes (34) originated from } \\
\text { collapsed salt mines (man-made or 'anthroposaline'), a few lakes (7) derived from natural dissolution of subterranean halite } \\
\text { deposits (natural or 'karstosaline'). }\end{array}$ \\
\hline Surface and depth & $\begin{array}{l}\text { - small surfaces (0.1 to ca. } 4 \mathrm{ha}) \text {; variable depths: from shallow }(1-3 \mathrm{~m}) \text { to deep lakes }(10-100 \mathrm{~m}) \text {, the latter developed } \\
\text { meromixis (see main text);- Ursu Lake (Sovata) is the largest }\left(41,270 \mathrm{~m}^{2}\right) \text { and deepest }(18.20 \mathrm{~m}) \text { karstosaline lake; the } \\
\text { Ferdinand - } 1 \text { Mai (Ocna Mureş) and Ocniţa - Avram Iancu (Ocna Sibiului) lacustrine complexes are the largest } \\
\left(143,875 \mathrm{~m}^{2}\right) \text {, and deepest }(127.10 \mathrm{~m}) \text { man-made lakes, respectively. }\end{array}$ \\
\hline $\begin{array}{l}\text { Hydrology and } \\
\text { circumlacustrine } \\
\text { vegetation }\end{array}$ & $\begin{array}{l}\text { - most are land-locked basins relying on meteoric water; only a few (e.g., Ursu Lake) are fed with permanent water sources } \\
\text { (e.g., rivulets); - most lakes are surrounded by scarce (cut-grass) vegetation and only a few (i.e., lakes in Sovata area) are } \\
\text { surrounded by lush (forest) vegetation. }\end{array}$ \\
\hline Salinity & $\begin{array}{l}\text { - the majority of lakes (37) are brackish to moderately saline (1-10\% salinity) in surface, whereas } 4 \text { lakes are hypersaline } \\
(10-20 \% \text { salinity) from surface. }\end{array}$ \\
\hline
\end{tabular}

Tab. 2. Morphometric elements of the representative lakes from Transylvania.

\begin{tabular}{|c|c|c|c|c|c|c|c|c|c|c|c|c|}
\hline Lake & Elem./Year & Surface $\left(m^{2}\right)$ & Lenght(m) & $\mathbf{B}_{\mathrm{m}}(\mathrm{m})$ & $\mathbf{B}_{\max }(\mathbf{m})$ & $\mathbf{h}_{\mathrm{m}}(\mathrm{m})$ & $\mathbf{h}_{\max }(\mathbf{m})$ & $\mathrm{A}(\mathrm{m})$ & $a(m)$ & Perimeter(m) & $\mathrm{C}_{\mathrm{s}}$ & Volume $\left(\mathrm{m}^{3}\right)$ \\
\hline Ursu & $1955^{\mathrm{a}}$ & 41702 & 457.53 & 91.14 & 183.81 & 12.65 & 18.90 & 366.76 & 243.05 & 1257.2 & 1.74 & 489,966 \\
\hline $2002^{\mathrm{b}}$ & 41270 & 455.95 & 90.51 & 204.61 & 11.84 & 18.20 & 366.02 & 238.78 & 1223.3 & 1.70 & 488675 & \\
\hline Ocnei & $1972^{c}$ & 1653.8 & 53.75 & 30.64 & 45.75 & 11.67 & 34.7 & 53.75 & 45.75 & 151.5 & 1.05 & $19,289.1$ \\
\hline $2005^{\mathrm{b}}$ & 2134.3 & 59.7 & 35.75 & 51.3 & 12.30 & 33.3 & 59.7 & 51.3 & 176.4 & 1.08 & 26249.4 & \\
\hline Rotund & $1972^{\mathrm{c}}$ & 470 & 28.75 & 16.35 & 23.25 & 4.86 & 15.6 & 28.75 & 23.25 & 78.15 & 1.02 & 2243.3 \\
\hline $2005^{\mathrm{b}}$ & 624.8 & 32.8 & 19.05 & 25.5 & 3.28 & 13.8 & 32.8 & 25.5 & 97 & 1.09 & 2050.6 & \\
\hline Fără Fund & $1973^{d}$ & 1655.0 & 55.0 & 30.10 & 47.8 & 6.72 & 32.95 & 55.0 & 47.75 & 151.5 & 1.05 & 11,114 \\
\hline $2000^{\mathrm{b}}$ & 1672.2 & 52.2 & 32.03 & 59.02 & 6.04 & 32.0 & 52.2 & 59.02 & 156.3 & 1.08 & 10098.4 & \\
\hline Brâncovean & nu $2000^{b}$ & 1601.2 & 54.1 & 29.6 & 42.9 & 4.88 & 14.5 & 51.4 & 42.9 & 151.3 & 1.07 & 7811.6 \\
\hline
\end{tabular}

$B_{m}$, average width; $B_{\max }$, maximum width; $h_{m}$, mean depth; $h_{\max }$ maximum depth; $A$, long axis; a, short axis; $P$, perimeter; $C_{s}$, sinuosity coefficient. aPișota, 1960; ' ${ }^{b}$ Alexe (2010); ' Pânzaru, 1974; 'Pânzaru, 1977. 
tained at a constant level by an artificial drainage channel towards the Sărata Valley. Lake Ocnei (46³5' N; 234' E) resulted from the collapse of an old salt mine around 1800 (Pânzaru, 1974). It has a circular shape, characteristic to bell-shaped salt lakes, with a small surface area and steep morphological profile (Fig. 2, Tab. 2). Ocnei Lake is permanently density-stratified (meromictic) with hypersaline monimolimnion and thus, develops heliothermy (i.e., $>30^{\circ} \mathrm{C}$ at 1.5-3 $\mathrm{m}$ depth) during summer. Situated nearby Ocnei Lake, Rotund Lake has a circular shape and a depth over 10 meter (Fig. 2, Tab. 2). It is heliothermal during summer and is one of the few saline lakes with steady morphological stability over time (i.e., no substantial changes in depth and surface) (Tab. 2).

Ocna Sibiului is situated in the southern Transylvania (15 km NW of Sibiu city) (Fig. 2) and is place of the largest salt lake complexes in Romania that currently includes 14 lakes out of which 12 being of man-made origin. Among these lakes, Fără Fund ('Bottomless' - 45'52'34", $\mathrm{N}$; 2404'03" E) and Brâncoveanu (45 $52^{\circ} 18^{\prime \prime} \mathrm{N}$; $24^{\circ} 03$ '56" E) are best explored to date (Andrei et al., 2015, 2017a). Both lakes resemble in their origin, morphometry, and limnology. They resulted by the collapse of bellshaped salt mines following water seepage and salt dissolution during $17^{\text {th }}$ (Brâncoveanu) and $18^{\text {th }}$ Cemtury (Fără Fund). Both are land-locked (i.e., no permanent water input), small-surfaced, circular lakes with steep shores and significant depths (Fig. 2, Tab. 2). The distinctiveness of these lakes resides in their unusual hypersaline $(>17 \%$, $\mathrm{w} / \mathrm{v}$, total salts) surface due of the direct contact between water and salt massif. Brâncoveanu and Fără Fund lakes have been long time (since ca. 150 years ago) capitalized for recreational and therapeutic purposes for their hypersaline and heliothermal water alongside sapropelic muds. Similarly to Ursu Lake in Sovata, Fără Fund Lake is currently a nature reserve with a strict conservation status.

Numerous deep Transylvanian salt lakes are meromictic with the water column perenially layered into three physico-chemically distinct strata: a surficial one (mixolimnion, down to ca. $3 \mathrm{~m}$ depth), usually less saline (2-10\% salinity), oxygenated and prone to $\mathrm{pH}$, temperature and dial light fluctuations; a transition layer (chemocline, at 3-4 $\mathrm{m}$ depth) characterized by a sharp shift of salinity, dissolved oxygen concentration, $\mathrm{pH}$, and, sometimes, oxidoreduction potential (ORP); and a bottom layer (monimolimnion, below $4 \mathrm{~m}$ depth) that is permanently hypersaline ( $>30 \%$ salinity), suboxic/anoxic $\left(<0.1 \mathrm{mg} \cdot \mathrm{L}^{-1}\right.$ $\left.\mathrm{O}_{2}\right)$, aphotic, slightly acidic $(\mathrm{pH} \sim 6)$, and, in some cases such as Ursu Lake, highly reduced (>-200 mV) (Fig. 3a). In addition, water temperature of the monimolimnion is constantly around $20^{\circ} \mathrm{C}$ (Fig. 3a) (Andrei et al., 2015; personal observations). Besides the three-layered model presented above, there are a few examples of Transylvanian lakes such as Fără Fund and Brâncoveanu that features a double-layered water column mainly because the water mass is extremely salty ( $>17 \%$ salinity) starting from the

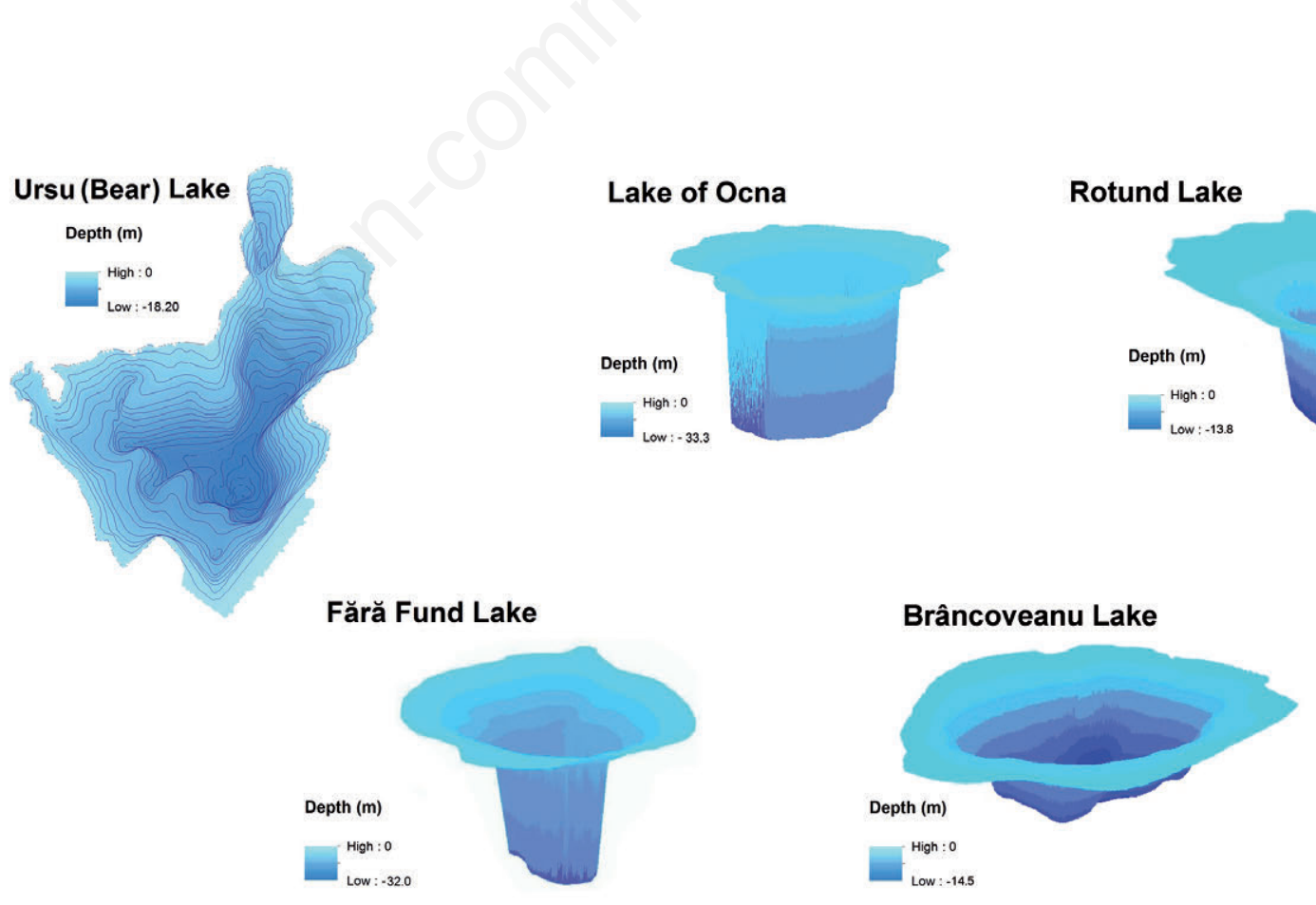

Fig. 2. Three dimensional images of the best investigated lakes to date: Ursu Lake (Sovata area), Ocnei and Rotund lakes (Turda area), Fără Fund and Brâncoveanu lakes (Ocna Sibiului area). 
surface (Fig. 3a). Therefore, salinity gradient is only slightly increasing along the water column, with a minor halocline situated at ca. 2-2.5 m depth, at a lesser depth than in other meromictic lakes (e.g., such as Ursu, Ocnei or Rotund) where halocline is at ca. 3-3.5 m depth (Baricz et al., 2014; 2015; Andrei et al., 2015; 2017a).

The meromictic nature of Transylvanian salt lakes such as Ocnei, Rotund, Brâncoveanu, Fără Fund, and Ursu lakes was revealed by in situ, multi-year (20092016) survey using a field multiparameter (pH/ORP/T/DO/salinity-meter, HI9828 model, Hanna Instruments) (Alexe, 2010; Baricz et al., 2014; Andrei et al., $2015,2017 \mathrm{a}$ ) and it was corroborated by the chemical analysis of water samples collected from different depths (Baricz et al., 2014; Máthé et al., 2014; Andrei et al., 2015, 2017a, our unpublished data). Overall, the water chemistry indicated the dominance of $\mathrm{Na}^{+}$and $\mathrm{Cl}^{-}$that contribute to $>90 \%$ of the total salts, followed by $\mathrm{K}^{+}, \mathrm{Ca}^{2+}$, $\mathrm{Mg}^{2+}$ among cations, and $\mathrm{SO}_{4}{ }^{2-}$ and $\mathrm{HCO}_{3}{ }^{-} / \mathrm{CO}_{3}{ }^{-2}$ among inorganic anions. Sulfate $\left(\mathrm{SO}_{4}{ }^{2-}\right)$ and ammonium $\left(\mathrm{NH}_{4}^{+}\right)$ profiles followed that of salinity, with highest values detected in the deeper strata. The highly-reduced sulfides (mostly as $\mathrm{H}_{2} \mathrm{~S}$ ) and methane $\left(\mathrm{CH}_{4}\right)$ were in significant ( $\sim 5 \mathrm{mM}$ and $0.06-0.3 \mathrm{mM}$, respectively) concentration in the bottom brine of Ursu Lake (Bulgăreanu et al., 1978; Máthé et al., 2014; Andrei et al., 2015) while sporadically detected in trace amounts in monimolimnion of Fără Fund Lake (Andrei et al., 2015; our unpublished data). The depth-dependent increase of highly reduced compounds is common among perennially stratified saline lakes. In meromictic brackish or saline lakes, sulfide- and ammonium-enriched bottom waters were reported in Lake A (Arctic Canada) (Gibson et al., 2002), Lake Mahoney (British Columbia, Canada) (Klepac-Ceraj et al., 2012),

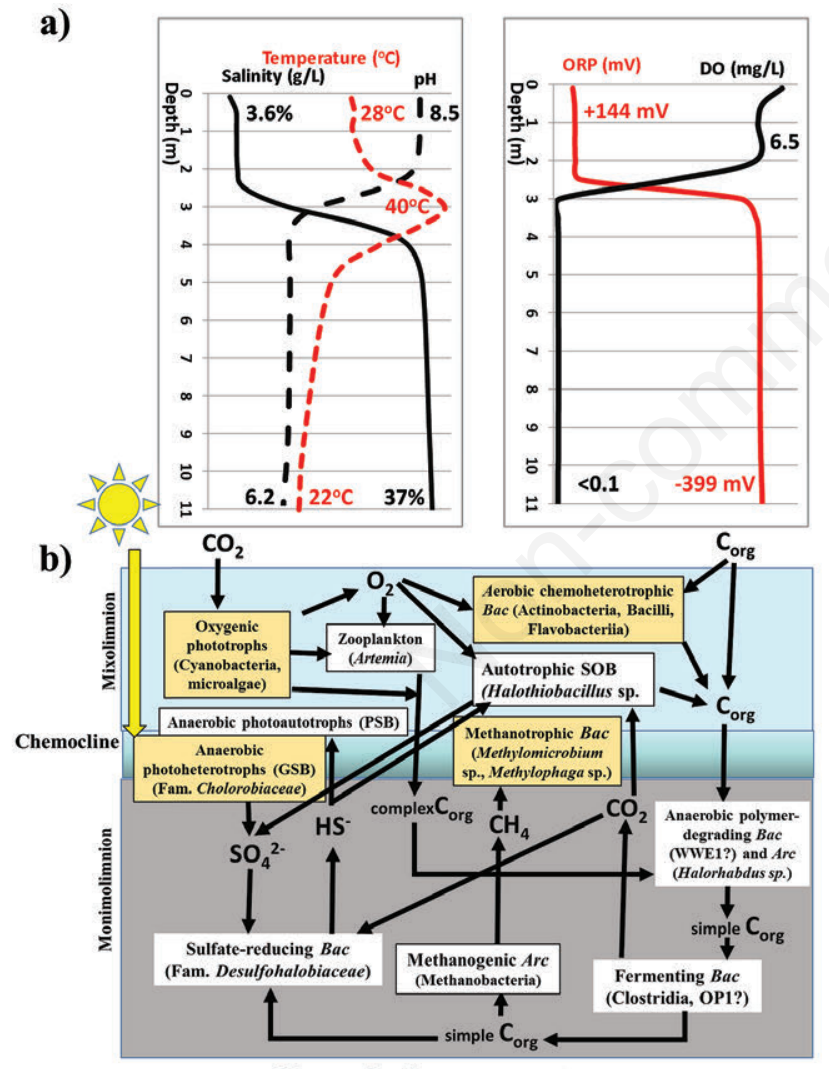

Ursu Lake ecosystem

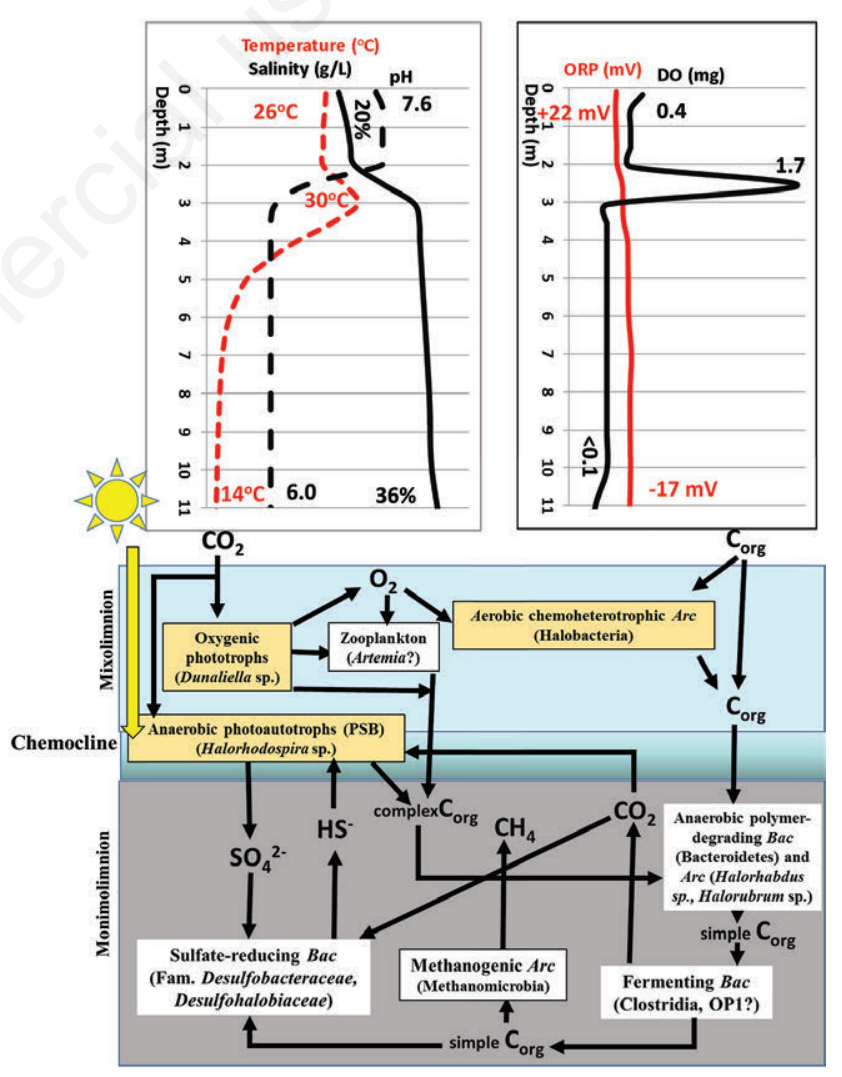

Fără Fund Lake ecosystem

Fig. 3. a) Physico-chemical stratification of Ursu (left) and Fără Fund lakes (right) during 2015 summer season. The heliothermy is observable as temperature peak below surface; relevant values for salinity (black line), temperature (red dotted line), $\mathrm{pH}$ (black dotted line), DO (black line), and ORP (red line) are shown. b) The proposed biogeochemical cycling of carbon and sulfur in two aquatic meromictic systems, Ursu (left) and Fără Fund (right), based on DNA metabarcoding approach employed by Andrei et al. (2015). The metabolic groups that differed among two lakes are highlighted in red background. DO, dissolved oxygen concentration; ORP, oxidoreduction potential; $\mathrm{C}_{\text {org }}$, organic carbon (complex $\mathrm{C}_{\text {org }}$ - polymeric substances of plant or animal origin; simple $\mathrm{C}_{\text {org }}$, monomers used by fermenters and 1C or 2/3C fermentation products, respectively); Arc, Archaea; Bac, Bacteria; SOB, sulfur-oxidizing bacteria. 
Kaiike (SW Japan) (Koizumi et al., 2004b), Shira and Shunet lakes (Southern Siberia) (Baatar et al., 2016); methane and ammonia are dominant reduced species in the anoxic monimolimnion of Ace Lake (Eastern Antarctica) (Laybourn-Parry and Bell, 2014) whereas ammonia $\left(\mathrm{NH}_{3}\right)$, sulfides and, sometimes, methane coexist at high concentration in anoxic monimolimnia of saline alkaline Big Soda, Mono, and Soap lakes (Kharaka et al., 1984; Joye et al., 1999; Humayoun et al., 2003; Sorokin et al., 2007; Dimitriu et al, 2008) (see also Tab. 3).

The main factor driving the permanent stratification of water column is the steady density gradient favoring the surface, less dense horizon to lay on the top of much denser water. The high depth and the stagnancy (that is, the lack of water intermixing) are the additional ingredients to make true meromictic aquatic systems (Boehrer and Schultze, 2008; Zadereev et al., 2017). Thus, in such systems, dramatic change of physico-chemical properties (see above and Fig. 3a) occurs at relatively short distance (meters or even centimeters) resulting in the formation of largely distinct micro-habitats. Niche differentiation along water column was observed in the meromictic saline Transylvanian lakes particularly when nutrient (bicarbonate/carbonate, sulfate, sulfides, ammonium, total phosphorous, total organic nitrogen, total organic carbon, etc.) and biological parameters (total photosynthetic pigments, total cell), were evaluated. In this regard, the zonated water column allowed predicting roughly three distinct ecological niches: i) the surface, less or moderately saline, oxic, and euphotic zone, highly impacted by environmental fluctuations favorable to non-halophilic and halotolerant aerobic macro- and microorganisms and to light-dependent aerobic primary producers (e.g., algae, cyanobacteria); ii) the intermediate, chemocline zone that, on an approximate distance of $1 \mathrm{~m}$, harbors a sudden transition from oxic to suboxic/anoxic, from euphotic to aphotic, and from saline to hypersaline conditions; this layer is apparently hosting several sub-niches where subpopulation of halotolerant and halophilic aerobic, microaerophilic and anaerobic photo- and chemotrophs might flourish; iii) the deep, dark, suboxic/anoxic, and hypersaline water layer, most probably to be inhabited by

Tab. 3. Main limnological and physico-chemical features of meromictic brackish, moderately saline, hypersaline, and alkaline saline lakes with substantial records in the literature. Ursu Lake was chosen as representative meromictic lake from the Transylvanian Basin.

\begin{tabular}{|c|c|c|c|c|c|c|c|c|c|}
\hline Characteristics & Mahoney & Ace & Organic & Kaiike & Shunet & Solar & Mono & Soap & Ursu \\
\hline Area $\left(\mathrm{km}^{2}\right)$ & 0.20 & 0.18 & 0.047 & 0.15 & 0.47 & 0.72 & 160 & 3.4 & 4.1 \\
\hline Max. depth (m) & 18 & 25 & 7.5 & 11.6 & 6.2 & 5 & 45 & 27 & 18.6 \\
\hline Origin & Athalassic ${ }^{\circ}$ & Thalassic & Thalassic & Thalassic & Athalassic & Thalassic & Athalassic ${ }^{\#}$ & \multicolumn{2}{|c|}{ Athalassic ${ }^{\#}$ Athalassic } \\
\hline Heliothermy observed & Yes $(2 \mathrm{~m})$ & Yes $(8 \mathrm{~m})$ & No & Yes $(4 \mathrm{~m})$ & No & Yes $(2.5-3 \mathrm{~m})$ & No & No & Yes $(2.5-3 \mathrm{~m})$ \\
\hline \multicolumn{10}{|l|}{ Mixolimnion } \\
\hline Salinity (\%) & $1.7-2.9$ & $1.3-2$ & $16.6-18$ & $0.2-0.3$ & 1.76 & $3.5-5$ & 7.7-9.4- & $1.2-1.8$ & $6-13$ \\
\hline $\mathrm{pH}$ & 8.9 & $8.2-8.3$ & 7.7 & 8.2 & 7.05 & $8.0-8.2$ & 9.8 & 7.7 & $7.6-8.7$ \\
\hline Chemocline depth (m) & $7-10$ & 12.7 & $5-5.5$ & 4.5 & 5 & $\begin{array}{rr}1-1.25 & 10 \\
& 23\end{array}$ & $\begin{array}{l}0-17 \text { (oxicline) } \\
-26 \text { (pycnoclin }\end{array}$ & , $18.5-21$ & 3.5 \\
\hline
\end{tabular}

\begin{tabular}{lccccccccc} 
Monimolimnion & & & & & & & \\
Salinity (\%) & $6-7$ & 2.24 .3 & $20-23$ & 3.4 & 8.1 & $18-20$ & $8.8-9.8$ & 14 & 35 \\
\hline $\mathrm{pH}$ & 7.35 & 7.0 & 7.0 & 7.7 & 5.8 & 6.9 & $9.8^{8}$ & 9.9 & 6.0 \\
\hline $\mathrm{S}^{2-}(\mathrm{mM})$ & $30-35+\mathrm{PS} 0.2-0.4 \mathrm{mM}$ & $4-8$ & as DMS $(5 \mu \mathrm{M})$ & $1-2$ & $13-15$ & 1.2 & $0.4-3$ & $125-200$ & $2.5-5.0$ \\
\hline $\mathrm{NH}_{4}^{+}(\mathrm{mM})$ & $5-8.8$ & $\mathrm{Nm}$ & $0.13-0.3$ & 0.3 & $\mathrm{Nm}$ & $0.001-0.005$ & 0.1 & $\mathrm{Nd}$ & 2 \\
\hline $\mathrm{NH}_{3}(\mathrm{mM})$ & $\mathrm{Nd}$ & 0.035 & $\mathrm{Nm}$ & $\mathrm{Nd}$ & $\mathrm{Nm}$ & $\mathrm{Nd}$ & 0.5 & $59-65$ & $\mathrm{Nm}$ \\
\hline $\mathrm{CH}_{4}(\mathrm{mM})$ & $\mathrm{Nd}$ & $\sim 0.02$ & $\mathrm{Nd}$ & $\mathrm{Nd}$ & $\mathrm{Nm}$ & 0.006 & $0.002-0.055^{\mathrm{S}}$ & $1^{\mathrm{S}}$ & $0.06-0.3$ \\
\hline $\mathrm{ORP}(\mathrm{mV})$ & $\mathrm{Nm}$ & $\mathrm{Nm}$ & + & $\mathrm{Nm}$ & -350 & -185 & $\mathrm{Nm}$ & $\mathrm{Nm}$ & -300
\end{tabular}

${ }^{*}$ During stable stratification period; ' sulfate and divalent cation $\left(\mathrm{Mg}^{2+}\right.$ and $\left.\mathrm{Ca}^{2+}\right)$-rich ecosystem; ${ }^{*} \mathrm{Na}^{+}$is main cation, $\mathrm{CO}_{3}{ }^{2-}+\mathrm{HCO}_{3}^{-}$and $\mathrm{Cl}^{-}$(in roughly equal proportion) are major anions; $\xi_{n o}$ published values for $\mathrm{pH}$ in deep water were found, however, the entire water mass is strongly buffered at $\mathrm{pH}$ 9.8-10.0; 'originally, the reduced nitrogen species reported was ammonia $\left(\mathrm{NH}_{3}\right)$; ${ }^{s}$ high methane (alongside low molecular weight alkanes) is explained partly by thermogenic gas seeps in Mono Lake whereas no clear explanations exist for Soap Lake. PS, polysulfides $\left(S_{n}^{2-}\right)$; DMS, dimethylsulfides; Nm, not measured; Nd, not detected. References: Mahoney Lake-Northcote and Hall, 1983; Hall and Northcote, 1986; Klepac-Ceraj et al., 2012; Organic Lake-Franzmann et al., 1987; Gibson, 1999; Yau et al., 2013; Ace Lake-Gibson, 1999; Rankin et al., 1999; Laybourn-Parry and Bell, 2014; Kaiike Lake-Matsuyama, 1977; Koizumi et al., 2004b; Ohkouchi et al., 2005; Shunet Lake-Degermendzhy et al., 2010; Baatar et al., 2016; Solar Lake - Cohen et al., 1977; Cytryn et al., 2000; Mono Lake - Jellison and Melack, 1993; Joye et al., 1999; Humayoun et al., 2003; Soap Lake - Walker, 1974; Oremland and Miller, 1993; Dimitriu et al., 2008; Ursu Lake-Máthé et al., 2014; Andrei et al., 2015; our unpublished results. 
extreme halophilic anaerobic microorganisms that derive energy from chemical reactions only. This picture was indeed, largely confirmed by the assessment of microbial diversity by culture-dependent and molecular techniques (see below).

\section{Eukaryotic and prokaryotic diversity in saline Transylvanian lakes}

Early evaluations of biodiversity associated with ecosystems of Transylvanian salt lakes mostly concerned littoral, planktonic and benthic flora and fauna (Maxim, 1931, 1936, 1941; Todor, 1947; Bulgăreanu et al., 1978; Pop and Hodișan, 1980; Spiridon et al., 1984; Ionescu et al., 1998). The circumlacustrine flora of saline lakes was represented by members of up to 60 families, with Poaceae and Asteraceae as most frequently encountered (Pop and Hodişan, 1980; Ionescu et al., 1998; Frink et al., 2013). A few halophytes (i.e., salt-adapted plants) were identified such as Puccinellia distans (Jacq.), Artemisia maritima (L.), Aster tripolium (L.), Inula britannica (L.), Suaeda maritima (L.) Dumort., and Salicornia europaea (L.) whereas the vast majority of vegetation surrounding investigated saline lakes comprised non-halophilic species (or 'glycophytes'). The listed halophytic species are typical components of vegetation associated with wet and highly saline (i.e., Puccinellietea) or extremely saline (i.e., Salicornietea) soils in Central and South-Eastern Europe, respectively (Piernik, 2005; Eliáš et al., 2013; Stevanović et al., 2016).

In contrast to salt lakes located in Cojocna, Turda, and Ocna Sibiului that are bordered by meadow or cut grass vegetation, the Sovata lakes are surrounded by lush, forestlike vegetation of 'Quercetum robur petrae' type comprised of deciduous trees (Quercus robur, Q. petraea, Alnus glutinosa, Fagus syilvatica, Carpinus betulus) and numerous grass species. Littoral or aquatic macrophytes are mostly represented by hydrohalophytes such as Potamogeton pectinatus (L.), Phragmites australis (Cav.) Trin. ex Steud., and Typha latifolia (L.) (Ionescu et al., 1998; Frink et al., 2013). These aquatic species have wide geographical range in wetlands with varying salinity (Hammer and Hesseltine, 1988; Santamaria, 2002). It is worth mentioning that the abundance of shore vegetation might have a consistent contribution to the allochtonous input of organic matter to the lake ecosystem (Fig. 3b) that ultimately would enhance the formation of organic-rich sediments (sapropels) of economic value (Bulgăreanu et al., 1978; 1983; 1989; Bulgăreanu, 1993). Following a survey on six tropical lakes, Talbot (1988) concluded that the accumulation of oil prone (i.e., organic-rich) lacustrine sediments is favored by a combination of high surface productivity (both as phytoplankton and higher plants input) and stable stratification regime of the water column.

Halotolerant (or 'euryhaline') representatives of green algae (Chlamydomonas sp., Picochlorum sp., Mantoniella sp. Enteromorpha sp.) and diatoms (Amphora sp., Navicula sp., Nitzschia sp., Surirella sp.) were identified both by microscopic (Bulgăreanu et al., 1978; Ionescu et al., 1998; our unpublished results) and molecular investigations (i.e., PCR-DGGE) (Keresztes et al., 2012; Máthé et al. 2014) in the phytoplankton of brackish or moderately saline (1-10\% salinity) shallow lakes or mixolimnia of meromictic Transylvanian lakes. Considered as marine native, the microalgae Picochlorum spp. were previously detected in inland saline pans (Henley et al., 2004), hypersaline lake in Tibet (Wu et al., 2009), and African soda lakes (Krienitz et al., 2012). By using pyrosequencing approach, Lauro et al. (2011) obtained Mantoniella sp.-related 18S rRNA gene sequences at high abundance in the mixolimnetic communities of Antarctic stratified Ace Lake. Analogous to the marine-derived Ace Lake's phytoplankton community, most of the unicellular green algae (Chlorophyta) and diatoms detected in Transylvanian salt lakes appeared as marine species that adapted to lacustrine conditions. However, the Transylvanian saline lakes are far more distant from any sea source than their equivalent Antarctic lakes (Keresztes et al., 2012).

Halophilic (or 'stenohaline') green algae Dunaliella sp. were abundantly observed (up to $7 \times 10^{3}$ cells $\cdot \mathrm{mL}^{-1}$ ) in hypersaline photic layer of lakes in Ocna Sibiului area (Ionescu et al., 1998; Keresztes et al., 2012; Somogyi et al., 2014; Andrei et al., 2015) (Fig. 4). Genus Dunaliella comprised obligate halophilic species $(D$. viridis and $D$. salina) with a broad salt range for growth from $0.9 \%$

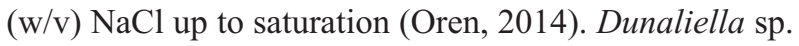
cells are thriving as major if not sole components of phytoplankton communities in hypersaline habitats such as high-salt lakes (e.g., Great Salt Lake where it reached peak density of 3-10 x $10^{3}$ cells $\cdot \mathrm{mL}^{-1}$, or Dead Sea where it recently vanished due to increase of divalent cation contents) and crystallizer ponds (e.g., Eilat, Israel - up to $3 \mathrm{x}$ $10^{3}$ cells $\cdot \mathrm{mL}^{-1}$, and Santa Pola, Spain - up to $10 \times 10^{3}$ cells $\cdot \mathrm{mL}^{-1}$ ) (Oren, 2014). Noteworthy, the Dunaliella salina (Dunal) Teod. was introduced as novel genus and species by the Romanian botanist Emanoil C. Teodorescu following his morphological and habitat description on living specimens collected from salt coastal lakes in SE Romania (Oren, 2014). A few observations on presence of Dunaliella sp. were made in lower euphotic layer (or upper chemocline) of deep, stratified saline lakes such as the alkaline saline Big Soda Lake (with a maximum density of $9.7 \times 10^{3}$ cells $\cdot \mathrm{mL}^{-1}$ ) (Priscu et al., 1982) and Antarctic ice-covered Organic Lake (up to $28 \times 10^{3}$ cells $\mathrm{mL}^{-1}$ ) (Franzmann et al., 1987).

The prokaryotic members of phytoplankton present in upper, photic and moderately saline (2-13\% salinity) layers of Transylvanian salt lakes include cyanobacteria of Synechococcus sp. (classified into marine Red Sea clade 
VIII by Keresztes et al., 2012), Chroococcus sp., Cryptomonas sp., Chrysococcus sp. (Bulgăreanu et al., 1978), Cyanothece sp., and Leptolyngbya sp. (Andrei et al., 2015, our unpublished results). These cyanobacteria are ubiquitous in freshwater, brackish or marine habitats and evidences on their occurrence in (hyper)saline environments (i.e., with salinity exceeding 7\%) are rather sparse.
For example, Chroococcus spp., Leptolyngbya spp., and Synechoccocus spp. alongside diatoms such as Nitzschia sp. were reported in crystallizer ponds with $11-18 \%(\mathrm{w} / \mathrm{v})$ total salts at Port Fouad, Egypt (Madkour and Gaballah, $2012)$; surficial microbial mats in shallow water $(\sim 8 \%$ salinity) of hypersaline, Solar Lake (Sinai, Egypt) harbored Synechococcus spp. and diatoms assigned to
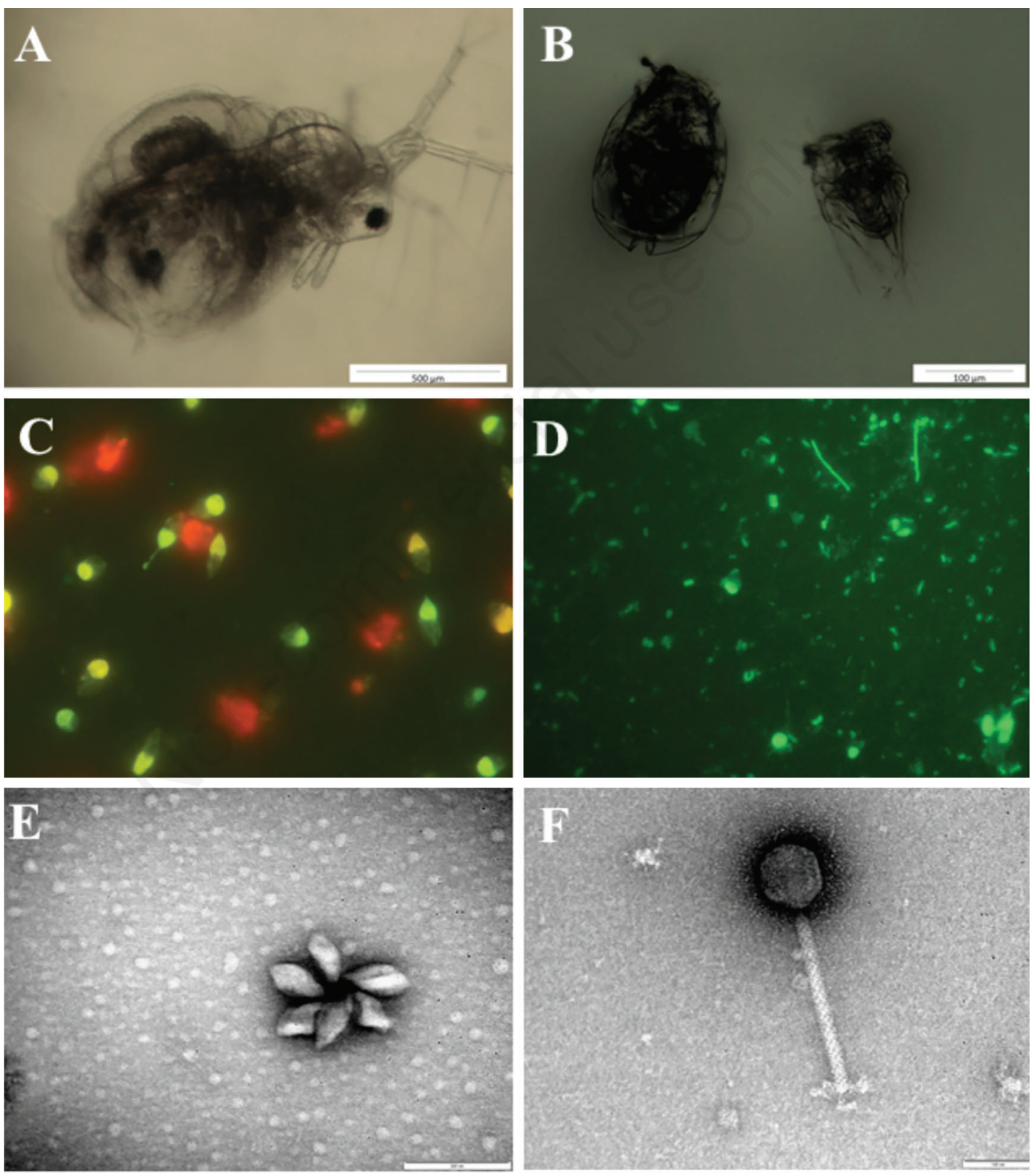

Fig. 4. Images of zoo-, phyto-, bacterio-, and virioplankton diversity in salt lakes of Transylvania: cladocerans (Moina salina, female) (A) and rotifers from Ursu Lake (Sovata) (B); epifluorescence microscopy of unicellular algae from Brâncoveanu Lake (Ocna Sibiului) (C); various microbial morphotypes in Tarzan Lake (Turda) observed in DAPI-stained samples (D); transmission electron microscopy of spindle-shaped (E) and isometric (F) viruses from Fără Fund lake (Ocna Sibiului). Scale bars: A) $500 \mu$ m; B), 100 m; E) 200 nm; F) 100 nm. 
Navicula, Nitzschia, and Amphora genera (Jørgensen et al., 1983) whereas Cyanothece spp. were observed as dominant cyanobacterium in the microbial mat $(\sim 18 \%$ salinity) of hypersaline, seasonally stratified Lake Hayward, SW Australia (Burke, 1995).

In surface layers (2-13\% salinity) of Transylvanian salt lakes, Somogyi et al. (2014) reported significant densities (i.e., $0.1-7.6 \times 10^{6}$ cells $\cdot \mathrm{mL}^{-1}$ ) of picophytoplankton cells (i.e., with diameter $<2 \mu \mathrm{m}$ and comprising mostly cyanobacteria but also microalgae such as Picochlorum sp. or Dunaliella sp.) suggesting a crucial role in the oxygen formation and light-dependent primary productivity in these saline aquatic ecosystems. In comparison, the brackish upper layers ( 2-3\% salinity) of marine-derived meromictic boreal Kaiike and Antarctic Ace lakes, the Synechococcus sp.-dominated phytoplankton peaks to $3 \mathrm{x}$ $10^{6}$ and $8 \times 10^{6}$ cells. $\mathrm{mL}^{-1}$, respectively (Koizumi et al., 2004b; Laybourn-Parry and Bell, 2014). It was suggested that the high abundance of picophytoplankton communities in Transylvanian salt lakes might be favored by the absence of grazers such as heterotrophic nanoflagellates that were, indeed, not observed in these lakes (Somogyi et al., 2014).

The zooplankton dwelling the oxic, brackish or moderately saline (2-13\% salinity) water layers of Transylvanian salt lakes include freshwater and marine copepods (Canthocamptus sp..), halotolerant cladocerans (Moina salina), calanoid (Arctodiaptomus salinus) and harpaticoid copepods (Cletocamptus retrogressus), and rotifers (Brachionus plicatilis) (Fig. 4) (Ionescu et al., 1998; personal observations). Dense populations of brine shrimp Artemia salina (Crustacea, Anostraca), a well-documented inhabitant of salt waters worldwide (Triantaphyllidis et al., 1998), were observed in the highly saline (up to $20 \%$ salinity) surface water of lakes located in Ocna Sibiului, Ocna Şugatag, Turda, and Sovata but further detailed investigations are lacking (Botnariuc and Orghidan, 1953; Bulgăreanu et al., 1996; Demeter and Stoicescu, 2008). The diversity of halotolerant and halophilic zooplankton in Transylvanian salt lakes is similar to that of coastal saline lakes in Spain (Alonso, 1990), salt pans and shallow saline lakes in Italy, Albania, and Crimea (Moscatello and Belmonte, 2009), and inland shallow saline lakes in SW Siberia (Litvinenko et al., 2013). A general distribution pattern was suggested for salt-adapted metazoans in which Anostraca (Artemia spp.) are frequently present in marinederived (thalassic) salt lakes or in hypersaline conditions, whereas halotolerant representatives of Copepoda (mainly calanoids) and Cladocera are likely distributed in continental (athalassic) and moderately saline bodies of water (Belmonte et al., 2012). Noteworthy, the cladoceran Moina salina was first described from Turda and Ocna Sibiului salt lakes, the Transylvanian Basin being indicated as its 'terra typica' (Negrea, 1984).

To predict the ecosystem functioning, several attempts were carried out to elucidate the abundance, diversity and possible metabolic roles of microorganisms in Transylvanian saline lakes. For example, the archaeal communities in Rotund, Ocnei, Fără Fund, Brâncoveanu, and Ursu lakes were assessed by traditional (culture-based) and molecular (culture-independent) methods (Baricz et al., 2014, 2015; Máthé et al., 2014; Andrei et al., 2015, 2017a) (Tab. 4). The quantitative Real-Time PCR (qPCR) analysis evidenced high archaeal cell densities $\left(\times 10^{6}\right.$ cells $\left.\mathrm{mL}^{-1}\right)$ in hypersaline Ocnei (6-110), Brâncoveanu (6-60), and Fără Fund lakes (0.44-140), a finding corroborated by the increased diversity of Archaea in these lakes (Baricz et al., 2014; Andrei et al., 2015; 2017a). High archaeal cell abundances were detected in hypersaline chemocline and monimolimnion of Ocnei Lake, throughout entire water mass in Brâncoveanu, and in mixolimnion and chemocline of Fără Fund Lake in contrast to Ursu Lake where bacterial cell densities (3.6-66.5 x $10^{6}$ cells $\left.\mathrm{mL}^{-1}\right)$ exceeded that of Archaea (0.8-2.4) along the entire water column. High ratio of archaeal to bacterial cell numbers was shown in hypersaline anoxic sediments of Salton Sea (California), where Archaea accounted for up to $99 \%$ of the total prokaryotes (Swan et al., 2010).

Best represented Archaea group in hypersaline Transylvanian lakes pertained to Halobacteria class (or 'haloarchaea') within Euryarchaeota phylum (Tab. 4). Haloarchaea include obligate halophiles relying on aerobic, facultatively or obligately anaerobic chemoheterotrophic metabolism (Andrei et al., 2012; Sorokin et al., 2017). At least 18 different haloarchaeal genera including the Haloferax sp., Halobacterium sp., Halorubrum sp. as most frequently encountered genera were retrieved both by culture and molecular approaches (Baricz et al., 2014, 2015; Andrei et al., 2015, 2017a). The culturable diversity of aerobic haloarchaea reported in the saline Transylvanian lakes exceeded that reported for other inland hypersaline habitats in Turkey, Iran, and Spain (Özcan et al., 2007; Makhdoumi-Kakhki et al., 2012; Luque et al., 2012). The most hypersaline lake Brâncoveanu ( $>20 \%$ salinity starting from surface) was found to harbor the highest diversity of archaeal community possibly including the recently described $\mathrm{Ha}$ lanaerorchaeum sulfurireducens with the unusual anaerobic $\mathrm{S}^{0}$-reducing metabolism (Sorokin et al., 2016). The $\mathrm{O}_{2}$-depleted hypersaline monimolimnia and bottom sediments of investigated salt lakes are preferred niches for microaerophilic Halomicrobium sp. or anaerobic, polymer-degrading haloarchaeon Halorhabdus sp. (Baricz et al., 2015; Andrei et al., 2015, 2017a). Based on the retrieved small-subunit ribosomal RNA (SSrRNA) gene sequences other archaeal groups were inferred including methanogens from Methanosarcinales (e.g., Methanohalobium sp.), MSBL1 candidate division, and Thermoplasmata (Máthé et al., 2014; Andrei et al., 2015) 
in Ursu and Fără Fund lakes, whereas reads related to uncultured archaeal divisions were detected in anaerobic layers of Ursu (Parvarchaea), Fără Fund (Parvarchaea and Nanohaloarchaea) (Andrei et al., 2015) and Brâncoveanu (Nanohaloarchaea) (Andrei et al., 2017a) lakes, respectively. Additionally, Parvarchaea was suggested as abundant component of microbial communities from hypersaline organic-rich sediments (sapropels) of Ursu and Fără Fund lakes (Andrei et al., 2017b). The ultrasmall-sized $(<0.8 \mu \mathrm{m})$ Nanohaloarchaea were identified by de novo assembly of metagenomes from hypersaline lakes (Lake Tyrell, Australia) and halite nodules (Atacama Desert) where they appear to thrive under aerobic and hypersaline conditions alongside members of Halobacteria (Ghai et al., 2011; Narasingarao et al., 2012; Podell et al., 2013; Crits-Cristoph et al., 2016). Whereas Nanohaloarchaea seem to occur in the hypersaline environments worldwide (Zhaxybayeva et al., 2013), members of Parvarchaea have not been yet evidenced in such systems. In this light, our finding of occurrence of Parvarchaea in hypersaline systems is unprecedented (Andrei et al., 2015).
Comprehensive efforts on revealing bacterial diversity in Transylvanian salt lakes showed a coherent picture of niche-based distribution of bacterial communities (Tab. 4). For example, numerous aerobic halotolerant or slightly halophilic chemoheterotrophic strains belonging to Gamma-Proteobacteria (Halomonas sp., Marinobacter sp., Salinivibrio sp., Idiomarina sp., Pseudoalteromonas sp.), or Firmicutes (Bacillus sp.) were isolated from the shallow and moderately saline Mierlei and Roșu lakes (2-15\% salinity, $2 \mathrm{~m}$ maximum depth) as well as from the mixolimnion of Ursu lake (2-10\% total salinity) (Borsodi et al., 2013; Crognale et al., 2013; Máthé et al., 2014). Insights into bacterial community composition were further retrieved by 16S rRNA gene clone library and DGGE in Mierlei, Roşu, and Ursu lakes (Borsodi et al., 2013; Crognale et al., 2013; Máthé et al., 2014) whereas a deeper resolution of microbial diversity along the water columns and sediments of Ursu and Fără Fund was gained by DNA metabarcoding analysis (Andrei et al., 2015; Andrei et al., 2017b). Thus, in the oxic, moderately saline (2-13\% salinity) water horizon of investigated lakes (Mierlei, Roșu, Ursu) in Sovata,

Tab. 4. Summary of bacterioplankton diversity of Transylvanian salt lakes explored to date.

\begin{tabular}{|c|c|c|}
\hline Water horizon/layer (depth) & Bacteria & Archaea \\
\hline $\begin{array}{l}\text { Shallow lakes and mixolimnia } \\
\text { of meromictic lakes }(0-2.5 \mathrm{~m}) \\
\text { with low-to-moderate salinity, } \\
\text { oxic conditions and fluctuating } \\
\text { environmental parameters }\end{array}$ & $\begin{array}{l}\text { Culture-dependent methods }{ }^{1,2,3} \text { Gamma-Proteobacteria } \\
\text { (Vibrio } \text { sp., Marinobacter sp., Salinivibrio } \text { sp., } \\
\text { Halomonas } \text { sp., Idiomarina } \text { sp.) and Firmicutes } \\
\text { (Marinoccoccus } \text { sp.) } \\
\text { Molecular methods (PCR-DGGE }{ }^{1} \text {, DNA }\end{array}$ & $\begin{array}{l}\text { Members of Halobacteria } \\
\text { (e.g. Halorubrum sp., Haloferax sp.) were detected } \\
\text { by culture-dependent }{ }^{1,4} \text { and molecular methods } \\
\text { (DNA metabarcoding }{ }^{5} \text { and } 16 \mathrm{~S} \text { rRNA-gene clone } \\
\text { libraries }{ }^{6,7} \text { ) mostly in hypersaline mixolimnia. }\end{array}$ \\
\hline
\end{tabular}
(temperature, $\mathrm{pH}$, light)

metabarcoding ${ }^{3,5}$ ) Actinobacteria, Flavobacteriia (Polaribacter sp., Psychroflexus sp.), Mollicutes, Bacilli, Planctomycetia (Planctomyces sp.), Alpha-Proteobacteria (Roseovarius sp., Beta-Proteobacteria, Gamma-Proteobacteria (Halorhodospira sp., Pseudoalteromonas sp.), Cytophagia

Transition zone $(2.5-4 \mathrm{~m})$ with steep salinity, $\mathrm{O}_{2}$, light, and $\mathrm{pH}$ gradients
Culture-dependent methods s $^{2,3}$ Gamma-Proteobacteria (Salinivibrio sp., Halomonas sp., Chromohalobacter sp.)

Firmicutes (Salimicrobium sp., Halobacillus sp.);

Molecular methods (PCR-DGGE ${ }^{2}$, DNA metabarcoding ${ }^{3,5}$ ) Actinobacteria, Nitriliruptoria, [Rhodotermi] ([Balneola] sp.), Chlorobia (Prosthecochloris sp.), Cyanobacteria (Synecochoccus sp.), Deferribacteres, Clostridia, Alpha-Proteobacteria, Gamma-Proteobacteria (Salinivibrio sp., Vibrio sp., Halothiobacillus sp.)

Monimolimnion (>4 $\mathrm{m}$ depth) Culture-dependent methods ${ }^{3}$ Gamma-Proteobacteria with constant physico-chemical conditions (i.e., hypersaline, suboxic/anoxic, aphotic)
Culture-dependent methods ${ }^{3}$ Gamma-Proteob
(Salicola sp., Idiomarina sp.) and Firmicutes

(Marinococcus sp.)

Molecular methods (DNA metabarcoding ${ }^{3,5}$ ): Actinobacteria, Firmicutes (Clostridia: Halanaerobium sp., Acetohalobium sp.), Chlorobi, Alpha-Proteobacteria, Gamma-Proteobacteria (Chromatiales, Halorhodospira sp.), Delta-Proteobacteria (Desulfovermiculus sp., Desulfovibrio sp.), [OD1], [OP1], [ABY1], [KB1]
Members of Halobacteria by culture-dependent ${ }^{1,4}$ and molecular methods libraries ${ }^{6,7}$ ) mostly in hypersaline mixolimnia

Members of Halobacteria were detected by traditional ${ }^{4}$ and molecular methods (DNA metabarcoding ${ }^{5}$ and $16 \mathrm{~S}$ rRNA-gene clone libraries ${ }^{6,7}$ ).

[Parvarchaea] candidate group was detected by DNA metabarcoding ${ }^{\mathrm{e}}$.

\footnotetext{
Culture-dependent methods ${ }^{4}$ Halobacteria (Halarchaeum sp., Natrinema sp., Haloferax sp., Halorubrum sp., Haloarchaeobius sp.,

Halomicrobium sp.)Molecular methods (DNA

metabarcoding 5 and $16 \mathrm{~S}$ rRNA-gene clone libraries $^{6,7}$ ) [Parvarchaea], Methanobacteria, Methanomicrobia, Thermoplasmata, Halobacteria (Salarchaeum sp., Halorhabdus sp., Halonotius sp., Halarchaeum sp., Haloarcula sp., Halobacterium sp. and others)
} 
most bacterial $\mathrm{OTU}_{0.03} \mathrm{~S}$ (Operational Taxonomic Units clustered at $97 \%$ cutoff similarity) pertained to aerobic heterotrophic representatives of Actinobacteria (Microbacteriaceae), Bacteroidetes (Balneolaceae, Cryomorphaceae), Alpha- (Rhodospirillaceae, Rhodobacteraceae), Beta- (Alcaligenaceae), and Gamma-Proteobacteria (Halomonadaceae and Altermonadales OM60 clade) (Borsodi et al., 2013; Crognale et al., 2013; Máthé et al., 2014; Andrei et al., 2015). The intermediate zone of Ursu Lake (that showed a steep halocline from 10 to $25 \%$ salinity paralleled by a sharp drop of dissolved oxygen concentration and photosynthetically active radiation over just $1 \mathrm{~m}$ vertical length) (Fig. 3a; Máthé et al., 2014; our observations), is shared by oxygenic phototrophs (Synechococcaceae, Cyanobacteria) (upper chemocline), green sulfur bacteria (GSB) of Chlorobiaceae (Cholorobi) (lower chemocline), Actinobacteria, Bacteroidetes, and Proteobacteria (Máthé et al., 2014; Andrei et al., 2015). Noteworthy, the moderately saline upper water layer of Ursu lake is largely inhabited by Bacteria ( $\sim 98 \%$ of $\mathrm{OTU}_{0.03}$ s relative abundance) in opposite to the hypersaline (20-25\% salinity) mixolimnion and chemocline of Fără Fund lake that appeared as ideal ecological niche for Archaea from Halobacteria class ( $\sim 5 \%$ relative abundance) seconded by Bacteroidetes (2-3\%) and Gamma-Proteobacteria (1-2\%). Reads belonging to the latter group were mostly assigned to extreme halophilic purple sulfur bacteria (PSB) of Ectothiorhodospiraceae (Halorhodospira sp.) that were scarcely found in Ursu water column. The bottom brines $(\sim 35 \%$, w/v, total salts) of Ursu and Fără Fund lakes accommodated roughly similar microbial communities with Bacteria $(65-70 \%$ relative abundances) prevailing over Archaea (ca. 25-30\%). $\mathrm{OTU}_{0.03} \mathrm{~S}$ assigned to anaerobic sulfate-reducing Delta-Proteobacteria (Desulfovermiculus sp.), extremely halophilic heterotrophic Clostridia (Halanaerobiaceae, Halanaerobacteroidaceae, and Clostridiaceae) and Spirochaetes (Spirochaetaceae) dominated among DNA metabarcodinginferred taxa. Intriguingly, sequences pertaining to uncultured or unclassified bacterial divisions (e.g., OP1/Acetothermia, OD1/Parcubacteria) were found at significant (1-2\%) abundances in the water columns and organic-rich sediments of Ursu and Fără Fund lakes (Andrei et al., 2015; 2017b).

To our knowledge, the Transylvanian deep, hypersaline, and perennially stratified aquatic systems have no match with analogous lakes worldwide. Besides freshwater systems such as European (Faro, Cadagno, Carinthian) or African tropical lakes, the best investigated meromictic lakes to date are either brackish (e.g., Antarctic lakes, Kaiike and Shira lakes), moderately saline (e.g., Shunet and Organic lakes), shallow hypersaline with holomixis episodes (Solar Lake, Sinai) or alkaline saline lake (e.g., Big Soda, Mono, and Soap lakes) (Zadereev et al., 2017). In most of the systematically explored meromictic brack- ish or saline lakes, the aerobic and versatile heterotrophic (e.g., Actinobacteria, Bacteroidetes, Verrucomicrobia, Alteromonadaceae and Halomonadaceae within GammaProteobacteria) and autotrophic (Cyanobacteria) bacterial communities prevailed in the euphotic mixolimnia (Lauro et al., 2011; Comeau et al., 2012; Yau et al., 2013). Generally, plates of low-light phototrophic PSB (Chromatiaceae) (Kaiike, Mahoney, Shira, and Shunet lakes) (Koizumi et al., 2004a; 2004b; Klepac-Ceraj et al., 2012; Baatar et al., 2016) and/or anoxygenic GSB (Chlorobiaceae) (e.g., Ace Lake, Arctic Lake A) (Lauro et al., 2011; Comeau et al., 2012) were found in the lower chemocline, at or just below oxic/anoxic transition zone. In most perennially stratified waters, the anoxic or euxinic (i.e., anoxic and $\mathrm{H}_{2} \mathrm{~S}$-rich) bottom layer is more taxonomically diverse than surface stratum. Sulfate-reducing DeltaProteobacteria, members of Firmicutes (Bacilli, Clostridia) (Mono, Mahoney, and Organic lakes) (Humayoun et al., 2003; Klepac-Ceraj et al., 2012; Yau et al., 2013), and candidate divisions OD1 (Organic and Ace lakes) (Lauro et al., 2011; Yau et al., 2013) or OP1 (Mahoney Lake) (Klepac-Ceraj et al., 2012) were detected as prevalent bacteria in anoxic bottom layers of brackish and saline meromictic lakes.

Not at least, it is worth mentioning that our attempts to shed light on the microbial diversity and its role in the trophic webs of the Transylvanian salt lakes has led to preliminary evidences for high-salt specific viral communities ('haloviruses') in the hypersaline Fără Fund lakes both by metagenomic and imaging tools (Fig. 4). Haloviruses may have significant role in controlling the abundance of halophilic microbial communities (Atanasova et al., 2015).

\section{Two models of ecosystem functioning in hypersaline meromictic lakes}

Permanently stratified, $\mathrm{pH}$-neutral saline aquatic systems apparently feature very similar limnological and environmental conditions. Considerable depth and stagnancy favor establishment of a density gradient and strong stratification of water column into three main layers and, implicitly, three distinct ecological niches (as described above and outlined in Tab. 1 and Fig. 3a). Thus, one would assume that analogous water layers would harbor similar diversity among meromictic lakes. However, our observation on the vertical distribution of microbial community composition in the two saline meromictic Ursu and Fără Fund lakes (Andrei et al., 2015) revealed major differences among related water layers, namely mixolimnion and chemocline. As consequence, distinct ecological functioning of the apparently similar aquatic systems could be envisaged. Although DNA metabarcoding approach is a good estimate for microbial diversity at a very fine scale, functionality of microbial communities 
can only be inferred by matching known taxa to taxonspecific metabolic function. Large pictures of biogeochemical cycling of main elements $(\mathrm{C}, \mathrm{N}, \mathrm{P}$, and $\mathrm{S})$ were drawn for meromictic Transylvanian salt lakes (Andrei et al., 2015) allowing distinction of two models of ecosystem functioning: 'Bacteria-dominated' and 'Archaeadominated' saline meromictic lakes with Ursu and Fără Fund lake, respectively, as model lakes (Fig. 3b).

The distinctiveness of the 'Bacteria-dominated' saline (Ursu) Lake as compared to the 'Archaea-dominated' (Fără Fund) lake is given by the significantly high abundance of bacteria-related sequences in the mixolimnion (0.5-2.5 m) and chemocline (3.5 m), whereas Archaea became apparent only in the lower chemocline $(3.5 \mathrm{~m})$ and monimolimnion $(9 \mathrm{~m})$. On the opposite, the epilimnion and chemocline of Fără Fund lake is clearly dominated by archaeal community whereas the monimolimnetic microbial diversity (with Bacteria slightly prevailing over Archaea) is roughly similar in both lakes. It seems that the combination of oxic, photic, and moderately saline conditions (2-15\% total salinity) in upper stratum of Ursu lake support dense aerobic chemoheterotrophic and halotolerant bacteria that might actively degrade organic matter of various origins, types and complexities as also demonstrated by community-level physiological profiling using BIOLOG Ecoplates ${ }^{\mathrm{TM}}$ approach (Cristea et al., 2014). Primary production in this type of lake is mainly driven by oxygenic phototrophic cyanobacteria and microalgae (Máthé et al., 2014; Andrei et al., 2015). The analogous but hypersaline ( $>17 \%$ salinity) water layer of Fără Fund lake is populated almost exclusively by haloarchaea (88-96\% relative abundance). Bacteria are scarcely (4-10\% relative abundance) represented by $\mathrm{OTU}_{0.03} \mathrm{~S}$ assigned to Bacteroidetes (Balneola sp. and Salinibacter sp.) and Proteobacteria (Halorhodospira sp.). Primary production is most probably achieved by the typical halophilic Dunaliella cells (Somogyi et al., 2013; Andrei et al., 2015) (Fig. 3b).

At chemocline (3.5 $\mathrm{m}$ and $2 \mathrm{~m}$ depth, respectively), alongside decrease in light intensity and DO, paralleled by increase in salinity and ORP seconded by presence of hydrogen sulfide (Máthé et al., 2014; Andrei et al., 2015), key steps in the sulfur and carbon cycling are driven by anoxygenic phototrophic GSB (Chlorobiaceae) in Ursu lake and by the PSB (Ectothiorhodospiraceae) in Fără Fund lake (Fig. 3b). Why GSB and PSB are solely present in each of the two lakes might be explained by an interplay of local conditions. In Ursu lake, the GSB requirements for lower light intensity (Damsté and Schouten, 2006; Zadereev et al., 2017) is fulfilled by the dense cyanobacteria 'plate' overlying GSB niche, whereas the PSB layer seemed better light-exposed in the presence of a sparse overlying population of phototrophic algae (Dunaliella sp.) thriving in hypersaline Fără Fund Lake
(Borsodi et al., 2013; Andrei et al., 2015).

Similar conditions in the bottom layer (i.e., dark, $\mathrm{O}_{2}$ deprived hypersaline water) are seconded by eutrophication that presumably feed in consistent organic carbon input in both lakes. Thus, apparently similar halophilic anaerobic communities dominated by sulfate-reducing bacteria (Desulfobacteraceae and Desulfohalobiaceae) and fermenters (Halobacteroidaceae and Halanerobiaceae) are harbored in analogous monimolimnia. Large quantities of organic matter of autochthonous (biomass formed by local primary producers added to debris of phyto- and zooplankton) and allochthonous (higher plant material, mainly leaves, from circumlacustrine vegetation) origins are sinking and slowly degraded (i.e., as deduced from the higher values of total organic carbon in the monimolimnion as compared to mixolimnion; Andrei et al., 2015; unpublished results). Complex polymers of plant and zooplankton origin are probably hydrolyzed by heterotrophic anaerobes such as the archaeon Halorhabdus to smaller $\mathrm{C}$ compounds (i.e., monomers). Monomers are further metabolized to $\mathrm{CO}_{2}$, formate, acetate, propionate etc. by fermenters (e.g., Halanaeobiales), whereas compounds such as methylamines derived from organic compatible solutes of decayed biomass may be consumed by methanogenic archaea (e.g.. Methanohalobium sp.) or by members of Acetothermia (OP1) and Parcubacteria (OD1) (detected in Ursu Lake). The latter, candidate lineages have been also demonstrated to occur in various anaerobic milieus including hypersaline mat of Guerrero Negro, Mexic (Ley et al., 2006) and water column of saline meromictic Shunet lake, Central Asia (Baatar et al., 2016). As result of intertwined metabolic activities of microbial communities inhabiting the three main layers, complete turnover of $\mathrm{C}, \mathrm{S}$ and, possibly, $\mathrm{N}$ and Fe, might be inferred in the both model meromictic lakes (Andrei et al., 2015) (Fig. 3b).

\section{Current conservation status and future challenges}

Fără Fund and Ursu (including its surrounding woodland) are the only Transylvanian salt lakes that have a protected status. Both lakes have been declared natural reserves since 1968 and 1970, respectively, and are currently included in the World Database on Protected Areas (WDPA ID 183748) and classified as 'natural monuments' by International Union for Conservation of Nature (IUCN Management category III). Fără Fund Lake is the only lake strictly prohibited for any sort of capitalization. The saline lakes in Transylvania are administered by local authorities and freely accessible to public or by public-private partnerships (i.e., exploited for recreational purposes by private or mixed private-public companies such as S.C. Salina Turda S.A., S.C. Balneoclimaterica S.A. in Sovata or S.C. Lacurile Naturale Ocna Sibiului S.A.). The touristic activities linked with salt lakes significantly contribute 
to the development of local economy in small cities such as Turda, Cojocna, Sovata or Ocna Sibiului. Most of the Transylvanian salt lakes are closed basins fed with meteoric water only and, therefore, particularly prone to alterations due to both anthropogenic activities (e.g., large influx of swimmers, modifications of the catchments) and change in Global climatic pattern (Williams, 1998). A plausible climate change scenario suggests the progression of the semi-arid Mediterranean climate towards central and east Europe with increasing of droughts periods and large variability of weather extremes (Schär et al., 2004). Through warming and negative water balance, enhanced evaporative concentration is expected to severely impact saline lakes especially (Benison and Bowen, 2015; Larson et al., 2016; Shadkam et al., 2016; Zachara et al., 2016). In this perspective, shallow saline lakes may desiccate, whereas the large or deep stratified water basins are susceptible to a more complicated evolution, possibly including eutrophication and hypoxia/euxinia (Raini, 2009; Lyons et al., 2009). However, short- to long-term water management plans need to be implemented to mitigate the climate change effects on inland aquatic systems (Shadkam et al., 2016). To preserve the most economically-valuable characteristics (i.e., gradient stratification, heliothermy, and potential for sapropel genesis), shortterm water management strategies (e.g., water quality monitoring, short bathing periods, water level control) are implemented to most saline lakes used for recreational purposes in Turda, Sovata or Ocna Sibiului areas (Bulgăreanu, 1993; 1996; Alexe, 2010).

\section{CONCLUDING REMARKS}

In this review, we highlighted the abiotic and biotic features of $\mathrm{pH}$-neutral salt lakes from the Transylvanian Basin, Central Romania. The thick halite deposits undelying Transylvanian Basin since Mid-Miocene Paratethys Sea regression were prerequisite for the genesis of salt lakes following mining activities or natural dissolution of salt rock. As consequence of the water chemistry (i.e., salt-rich) and morphometry (i.e., closed basins with significant depths), most of these lakes are meromictic and thus, harboring distinct micro-habitats along the water column. Recent studies in several saline Transylvanian lakes employing culture-dependent and molecular approaches pointed on the high ecological complexity with discrete niche-based distribution of plankton communities. Shift in the plankton community structure and composition is generally driven by the salinity and the availability of electron donors. In saline meromictic Transylvanian lakes, the bottom brines with stable abiotic conditions are apparently inhabited by similar, highly-diverse microbial assemblages relying on the downward flux of nutrients. A more lake-specific plankton diversity was described in the surface waters (mixolimnion and chemo- cline) that are likely impacted by environmental changes. During decades of investigations, all components of trophic chains were identified suggesting that these lakes are stable ecosystems with full biogeochemical cycling of major elements. Moreover, by their combined abiotic (i.e., limnology, geochemistry, and geographical positioning) and biotic (i.e., highly-diverse microbial communities and potentiality for novel prokaryotic lineages), the Transylvanian salt lakes appear as unique saline aquatic systems that may inspire future field- or laboratory-based experiments. Nonetheless, thorough understanding of relationships among trophic chain components that play major roles in ecosystem functioning as well as of adverse human and changing climate impacts is needed in support of local policies for durable management and protection of Transylvanian salt lakes.

\section{ACKNOWLEDGMENTS}

This work was supported by grants of the Romanian National Authority for Scientific Research, CNCS - UEFISCDI, project numbers PN-II-ID-PCE-2011-3-0546 and PN-III-P4-ID-PCE-2016-0303. We thank Professors A. Oren and R. Cavicchioli for their useful comments to the comparative table of meromictic lakes.

\section{REFERENCES}

Alexe M, 2010. [Study of salt lakes in the Transylvanian Basin].[Book in Romanian]. Cluj University Press, ClujNapoca: 241 pp.

Alexe M, Alexe I, 2008. The salt lakes from Ocna Dejului. Aspects regarding the evolution of lacustrine basins. Studia UBB Geographia 2:129-134.

Alexe M, Şerban G, Fülöp-Nagy J, 2006. [Salt lakes in Sovata].[Book in Romanian]. Casa Cărţii de Ştiinţă, ClujNapoca: 107 pp.

Alexe M, Şerban G, 2006. [The role of GPS and GIS in the diapiric dissolution areas management - case study: the salt lakes from Sovata].[Article in Romanian]. Geographia Technica 1:1-7.

Alexe M, Şerban G, 2014a. The evolution of heliotherm phenomenon in the karstosaline Lake Ursu from Sovata, Romania. Carpathian J. Earth Environ. Sci. 9:103-111.

Alexe M, Şerban G, 2014b. Spatial dynamic of some lacustrine salty areas using topographic and GPS surveys and GIS analysis in Transylvania, Romania - Case Study. Proceedings of the 14th GeoConference on Water Resources, Forest, Marine and Ocean Ecosystems, SGEM 2014, Albena, Bulgaria 2:793-800.

Alonso M, 1990. Anostraca, Cladocera and Copepoda of Spanish saline lakes. Hydrobiologia, 197:221-231.

Andrei A-Ş, Banciu HL, Oren A, 2012. Living with salt: metabolic and phylogenetic diversity of archaea inhabiting saline ecosystems. FEMS Microbiol. Lett. 330:1-9.

Andrei A-Ş, Baricz A, Păusan M, Muntean V, Sicora C, Alexe M, Rakosy-Tican E, Banciu HL, 2017a. Spatial distribution 
and molecular diversity of archaeal communities in the extreme hypersaline meromictic Brâncoveanu Lake (Transylvanian Basin, Romania). Geomicrobiol. J. 34:130-138.

Andrei A.-Ş, Baricz A, Robeson MS, Păuşan MR, Tămaş T, Chiriac C, Szekeres E, Barbu-Tudoran L, Levei EA, Coman C, Podar M, Banciu HL, 2017b. Hypersaline sapropels act as hotspots for microbial dark matter. Sci Rep. 7:6150.

Andrei A-Ş, Robeson MS, Baricz A, Coman C, Muntean V, Ionescu A, Etiope G, Alexe M, Sicora CI, Podar M, Banciu HL, 2015. Contrasting taxonomic stratification of microbial communities in two hypersaline meromictic lakes. ISME J. 9:2642-2656.

Atanasova NS, Oksanen HM, Bamford DH, 2015. Haloviruses of archaea, bacteria, and eukaryotes. Curr Opin Microbiol. 25:40-48.

Baatar B, Chiang PW, Rogozin DY, Wu YT, Tseng, CH, Yang, CY, Chiu HH, Oyuntsetseg B, Degermendzhy AG, Tang SL, 2016. Bacterial communities of three saline meromictic lakes in Central Asia. PloS One 11:e0150847.

Báldi K, 2006. Paleoceanography and climate of the Badenian (Middle Miocene, 16.4-13.0) in the Central Paratethys based on foraminifera and stable isotope evidence $\left(\delta^{18} \mathrm{O}\right.$ and $\left.\delta^{13} \mathrm{C}\right)$ evidence. Geol. Rundsch 95:119-142.

Baricz A, Coman C, Andrei A-Ş, Muntean V, Keresztes ZG, Păusan M, Alexe M, Banciu HL, 2014. Spatial and temporal distribution of archaeal diversity in meromictic, hypersaline Ocnei Lake (Transylvanian Basin, Romania). Extremophiles 18:399-413.

Baricz A, Cristea A, Muntean V, Teodosiu G, Andrei A-Ş, Molnár I, Alexe M, Rakosy-Tican E, Banciu HL, 2015. Culturable diversity of aerobic halophilic archaea (Fam. Halobacteriaceae) from hypersaline, meromictic Transylvanian lakes. Extremophiles 19:525-537.

Belmonte G, Moscatello S, Batogova EA, Pavlovskaya T, Shadrin NV, Litvinchuk LF, 2012. Fauna of hypersaline lakes of the Crimea (Ukraine). Thalassia Salentina 34:11-24.

Belovsky GE, Stephens D, Perschon C, Birdsey P, Paul D, Naftz D, Baskin R, Larson C, Mellison C, Luft J, Mosley R, Mahon H, Van Leeuwen J, Allen DV, 2011. The Great Salt Lake Ecosystem (Utah, USA): long term data and a structural equation approach. Ecosphere 2:1-40.

Benison KC, Bowen BB, 2015. The evolution of end-member continental waters: The origin of acidity in southern Western Australia. GSA Today 25:4-10.

Boehrer B, Schultze M, 2008. Stratification of lakes. Rev. Geophys. 46:RG2005.

Borsodi AK, Felföldi T, Máthé I, Bognár V, Knáb M, Krett G, Jurecska L, Toth EM, Márialigeti K, 2013. Phylogenetic diversity of bacterial and archaeal communities inhabiting the saline Lake Red located in Sovata, Romania. Extremophiles 17:87-98.

Botnariuc N, Orghidan T, 1953. Crustacea, Phyllopoda, Fauna Republicii Populare Române, IV(2). [Book in Romanian], Ed. Acad. RPR, București, pp. 99.

Bowman JP, McCammon SA, Rea SM, McMeekin TA, 2000. The microbial composition of three limnologically disparate hypersaline Antarctic lakes. FEMS Microbiol. Lett. 183:81-88.

Bulgăreanu VAC, 1993. The protection and management of saline lakes of therapeutic value in Romania. Int. J. Salt Lake Res. 2:165-171.
Bulgăreanu VAC, 1996. Protection and management of anthroposaline lakes in Romania. Lakes Reserv. Res. Manag. 2:211-229.

Bulgăreanu VAC, Ionescu-Teculescu V, Hannich D, Demeter F, 1978. New data regarding the hydrology, limnogeology and hydrobotany of heliothermic and pelogene lake Ursu (Sovata). [Article in Romanian with English abstract]. Acta Bot. Horti. Bucurestiensis (1977-1978):89-113.

Bulgăreanu VAC, Ionescu V, Ioanițescu E, 1989. The contribution of wood vegetation leaf material to the peloidogenesis in salt, meromictic and pelogenous lake Ursu - Sovata (Transylvania, Romania). Rev. Roum. Biol.-Biol. végét. 34:149-155.

Bulgăreanu VAC, Ionescu-Țeculescu V, Ioanițescu E, Stoica A, Țintilă D, 1983. Chemical changes of circum-lacustrine vegetation and the peloidogenesis in the salt, pelogenous lake Verde (Sovata, Romania). Rev. Roum, Biol.- Biol. végét. 28:101-107.

Bulgăreanu VAC, Ionescu-Țeculescu V, Năstăsescu M, Raclaru P, Cehlarov A, Hannich D, Moza D, 1978. On the limnology of the hypersaline lake Baia Miresii ('Muntele de sare' Slănic-Prahova). [In Romanian with English abstract]. Acta Bot. Horti Bucurestiensis (1977-1978):67-87.

Burke CM, 1995. Benthic microbial production of oxygen supersaturates the bottom water of a stratified hypersaline lake. Microb. Ecol. 29:163-171.

Ciupagea D, Paucă M, Ichim T, 1970. [Transylvanian Basin Geology]. [Book in Romanian], Editura Academiei R. S. România, Bucureşti.

Cristea A, Andrei A-Ș, Baricz A, Muntean V, Banciu HL, 2014. Rapid assessment of carbon substrate utilization in the epilimnion of meromictic Ursu lake (Sovata, Romania) by the BIOLOG ECO PLATE ${ }^{\text {TM }}$ approach. Studia UBB Biologia 59:41-53.

Cohen Y, Krumbein WE, Goldberg M, Shilo M, 1977. Solar lake (Sinai). 1. Physical and chemical limnology. Limnol. Oceanogr. 22:597-608.

Comeau AM, Harding T, Galand PE, Vincent WF, Lovejoy C, 2012. Vertical distribution of microbial communities in a perennially stratified Arctic lake with saline, anoxic bottom waters. Sci. Rep. 2:604.

Crognale S, Máthé I, Cardone V, Stazi SR, Ráduly B, 2013. Halobacterial community analysis of Mierlei saline lake in Transylvania (Romania). Geomicrobiol J. 30:801-812.

Crits-Christoph A, Gelsinger DR, Ma B, Wierzchos J, Ravel J, Davila A, Casero MC, DiRuggiero J, 2016. Functional interactions of archaea, bacteria and viruses in a hypersaline endolithic community. Environ. Microbiol. 18: 2064-2077.

Cytryn E, Minz D, Oremland RS, Cohen Y, 2000. Distribution and diversity of archaea corresponding to the limnological cycle of a hypersaline stratified lake (Solar Lake, Sinai, Egypt). Appl. Environ. Microbiol. 66:3269-3276.

Damsté JS, Schouten S, 2006. Biological markers for anoxia in the photic zone of the water column, p. 127-163. In: J.K. Volkman (ed.), Marine organic matter: Biomarkers, isotopes and DNA, Vol. 2: Reactions and processes, Springer-Verlag, Berlin.

Degermendzhy AG, Zadereev ES, Rogozin DY, Prokopkin IG, Barkhatov YV, Tolomeev AP, Khromechek EB, Janse JH, Mooij WM, Gulati RD, 2010. Vertical stratification of physical, chemical and biological components in two saline lakes 
Shira and Shunet (South Siberia, Russia). Aquat. Ecol. 44:619-632.

Demeter L, Stoicescu A, 2008. A review of the distribution of large branchiopods (Branchiopoda: Anostraca, Notostraca, Spinicaudata, Laevicaudata) in Romania. North-West. J. Zool. 4:203-223.

Deocampo DM, Renaut RW, 2016. Geochemistry of african soda lakes, p. 77-93. In: M. Schagerl (ed.), Soda Lakes of East Africa. Springer International Publishing, Switzerland.

Dimitriu PA, Pinkart HC, Peyton BM, Mormile MR, 2008. Spatial and temporal patterns in the microbial diversity of a meromictic soda lake in Washington State. Appl. Environ. Microbiol. 74:4877-4888.

Egorov AN, 1993. Mongolian salt lakes: some features of their geography, thermal patterns, chemistry and biology. Hydrobiologia 267:13-21.

Eliáš P, Sopotlieva D, Dítě D, Hájková P, Apostolova I, Senko D, Melečková Z, Hájek M, 2013. Vegetation diversity of salt-rich grasslands in Southeast Europe. Appl. Veg. Sci. 16:521-537.

Enache M, Itoh T, Kamekura M, Teodosiu G, Dumitru L, 2007. Haloferax prahovense sp. nov., an extremely halophilic archaeon isolated from a Romanian salt lake. Int. J. Syst. Evol. Microbiol. 57:393-397.

Franzmann PD, Deprez PP, Burton HR, Van den Hoff J, 1987. Limnology of Organic Lake, Antarctica, a meromictic lake that contains high concentrations of dimethyl sulfide. Aust. J. Mar. Freshwater Res. 38:409-417.

Frink JP, Balázs E, Máthé I, 2013. Floristic surveys in the Lake Ursu Nature Reserve and adjacent areas (Sovata, Transylvania, Romania). Brukenthal. Acta Musei 8:531-546.

Gâştescu P, 1971. Lakes in Romania. Regional limnology. [Book in Romanian]. Academy of Bucharest: 372 pp.

Ghai R, Pašić L, Fernández AB, Martin-Cuadrado AB, Mizuno CM, McMahon KD, Papke RT, Stepanauskas R, RodriguezBrito B, Rohwer F, Sánchez-Porro C, Ventosa A, RodríguezValera F, 2011. New abundant microbial groups in aquatic hypersaline environments. Sci. Rep. 1:135.

Gibson JA, 1999. The meromictic lakes and stratified marine basins of the Vestfold Hills, East Antarctica. Antarctic Sci.11:175-192.

Gibson JA, Vincent WF, Van Hove P, Belzile C, Wang X, Muir D, 2002. Geochemistry of ice-covered, meromictic Lake A in the Canadian High Arctic. Aquat. Geochem. 8:97-119.

Hall KJ, Northcote TG, 1986. Conductivity-temperature standardization and dissolved solids estimation in a meromictic saline lake. Can. J. Fish. Aquat. Sci. 43:2450-2454.

Hammer UT, 1986. Saline lake ecosystems of the world. Kluwer Academic, Dordrecht.

Hammer UT, Heseltine JM, 1988. Aquatic macrophytes in saline lakes of the Canadian prairies. Hydrobiologia 158:101-116.

Har N, Rusz O, Codrea V, Barbu O, 2010. New data on the mineralogy of the salt deposit from Sovata (Mureş County-Romania). Carpathian J Earth Environ Sci. 5:127-135.

Henley WJ, Hironaka JL, Guillou L, Buchheim MA, Buchheim JA, Fawley MW, Fawley KP, 2004. Phylogenetic analysis of the 'Nannochloris-like'algae and diagnoses of Picochlorum oklahomensis gen. et sp. nov. (Trebouxiophyceae, Chlorophyta). Phycologia 43:641-652.
Hudec PP, Sonnenfeld P, 1989. Comparison of composition and concentration of some lagoonal and continental brine lakes. Sedim. Geol. 64:265-270.

Humayoun SB, Bano N, Hollibaugh JT, 2003. Depth distribution of microbial diversity in Mono Lake, a meromictic soda lake in California. Appl. Environ. Microbiol. 69:1030-1042.

Ionescu V, Năstăsescu M, Spiridon L, Bulgăreanu VA, 1998. The biota of Romanian saline lakes on rock salt bodies: A review. Int. J. Salt Lake Res. 7:45-80.

Irimuş IA, 1998. [The relief on the domes and diapiric layers in Transylvanian Basin].[Book in Romanian]. Presa Universitară Clujeană, Cluj-Napoca: 299 pp.

Irimuş IA, 2006. [Hazards and risks associated with geomorphological processes in the Transylvanian Basin diapiric layers area]. [Book in Romanian]. Casa Cărţii de Ştiinţă, Cluj-Napoca: 287 pp.

Jellison R, Melack JM, 1993. Meromixis in hypersaline Mono Lake, California. 1. Stratification and vertical mixing during the onset, persistence, and breakdown of meromixis. Limnol. Oceanogr. 38:1008-1019.

Jørgensen BB, Revsbech NP, Cohen Y, 1983. Photosynthesis and structure of benthic microbial mats: microelectrode and SEM studies of four cyanobacterial communities. Limnol. Oceanogr. 28:1075-1093.

Joye SB, Connell TL, Miller LG, Oremland RS, Jellison RS, 1999. Oxidation of ammonia and methane in an alkaline, saline lake. Limnol. Oceanogr. 44:178-188.

Kalecsinszky S, 1901. [Über die Ungarischen warmen und heissen Koohsalzseen als natürliche Wärme-accumulatoren, sowie über die Herstellung von warmen Salzseen und Wärme-accumulatoren].[Article in German]. Földt. Közl. 31:409-431.

Keresztes ZG, Felföldi T, Somogyi B, Székely G, Dragoş N, Márialigeti K, Varga C, Vörös L, 2012. First record of picophytoplankton diversity in Central European hypersaline lakes. Extremophiles 16:759-769.

Kharaka YK, Robinson SW, Law LM, Carothers WW, 1984. Hydrogeochemistry of Big Soda Lake, Nevada: an alkaline meromictic desert lake. Geochim. Cosmochim. Acta 48: 823-835.

Klepac-Ceraj V, Hayes CA, Gilhooly WP, Lyons TW, Kolter R, Pearson A, 2012. Microbial diversity under extreme euxinia: Mahoney Lake, Canada. Geobiology 10:223-235.

Koizumi Y, Kojima H, Fukui M, 2004a. Dominant microbial composition and its vertical distribution in saline meromictic Lake Kaiike (Japan) as revealed by quantitative oligonucleotide probe membrane hybridization. Appl. Environ. Microbiol. 70:4930-4940.

Koizumi Y, Kojima H, Oguri K, Kitazato H, Fukui M, 2004b. Vertical and temporal shifts in microbial communities in the water column and sediment of saline meromictic Lake Kaiike (Japan), as determined by a $16 \mathrm{~S}$ rDNA-based analysis, and related to physicochemical gradients. Environ. Microbiol. 6:622-637.

Krienitz L, Bock C, Kotut K, Luo W, 2012. Picocystis salinarum (Chlorophyta) in saline lakes and hot springs of East Africa. Phycologia 51:22-32.

Larson R, Eilers J, Kreuz K, Pecher WT, DasSarma S, Dougill S, 2016. Recent desiccation-related ecosystem changes at Lake Abert, Oregon: a terminal alkaline salt lake. Western North Am Nat. 76:389-404. 
Lauro FM, DeMaere MZ, Yau S, Brown MV, Ng C, Wilkins D, Raftery MJ, Gibson JA, Andrews-Pfannkoch C, Lewis M, Hoffman JM, Thomas T, Cavicchioli R, 2011. An integrative study of a meromictic lake ecosystem in Antarctica. ISME J. 5:879-895.

Laybourn-Parry J, Bell EM, 2014. Ace Lake: three decades of research on a meromictic, Antarctic lake. Polar Biol. 37:1685-1699.

Lengyel B, 1898. [A Szovátai Illyés-Medve-tó].[Article in Hungarian]. Földt. Közl. 28:229-234.

Ley RE, Harris JK, Wilcox J, Spear JR, Miller SR, Bebout BM, Maresca JA, Bryant DA, Sogin ML, Pace NR, 2006. Unexpected diversity and complexity of the Guerrero Negro hypersaline microbial mat. Appl. Environ. Microbiol. 72: 3685-3695.

Litvinenko LI, Litvinenko AI, Boyko EG, Kutsanov KV, 2013. Effect of environmental factors on the structure and functioning of biocoenoses of hyperhaline water reservoirs in the south of Western Siberia. Contemp. Probl. Ecol. 6:252-261.

Luque R, González-Domenech CM, Llamas I, Quesada E, Béjar V, 2012. Diversity of culturable halophilic archaea isolated from Rambla Salada, Murcia (Spain). Extremophiles 16:205-213.

Lyons TW, Anbar AD, Severmann S, Scott C, Gill BC, 2009. Tracking euxinia in the ancient ocean: a multiproxy perspective and Proterozoic case study. Ann. Rev. Earth Planet. Sci. 37:507-534.

Máthé I, Borsodi AK, Tóth EM, Felföldi T, Jurecska L, Krett G, Márialigeti K, 2014. Vertical physico-chemical gradients with distinct microbial communities in the hypersaline and heliothermal Lake Ursu (Sovata, Romania). Extremophiles 18:501-514.

Matsuyama M, 1977. Limnological features of Lake Kaiike, a small coastal lake on Kamikoshiki Island, Kagoshima Prefecture, Japan. Jap. J. Limnol. 38:9-18.

Madkour FF, Gaballah MM, 2012. Phytoplankton assemblage of a solar saltern in Port Fouad, Egypt. Oceanologia 54:687-700.

Makhdoumi-Kakhki A, Amoozegar MA, Kazemi B, Pašić L, Ventosa A, 2012. Prokaryotic diversity in Aran-Bidgol salt lake, the largest hypersaline playa in Iran. Microbes Environ. 27:87-93.

Maxim IA, 1931. [Kontribution zur Erklärung des Erwärmungsprozesses der Salzteiche von Siebenbürgen. II. Die Teiche von Ocna-Sibiului]. [Article in Romanian with German abstract]. Rev. Muz. Geol.-Mineral. Univ. Cluj (1930) 4:47-111.

Maxim IA, 1936. [Kontribution zur Erklärung des Erwärmungsprozesses der Salzteiche von Siebenbürgen (Rumänien). III. Die Teiche von Turda].[Article in Romanian with German abstract]. Rev. Muz. Geol.-Mineral. Univ. Cluj (1936) 4:209-320.

Maxim IA, 1941. [Kontribution zur Erklärung des Erwärmungsprozesses der Salzteiche von Siebenbürgen (Rumänien). IV. Die Teiche von Sic (Someș)].[Article in Romanian with German abstract]. Rev. Muz. Geol.-Mineral. Univ. Cluj (19401941) 7:153-208.

Moscatello S, Belmonte G, 2009. Egg banks in hypersaline lakes of the South-East Europe. Saline Syst. 5:3.

Muntean V, Crisan R, Paşca D, Kiss S, Drăgan-Bularda M, 1996. Enzymological classification of salt lakes in Romania. Int. J. Salt Lake Res. 5:35-44.
Narasingarao P, Podell S, Ugalde JA, Brochier-Armanet C, Emerson JB, Brocks JJ, Heidelberg KB, Banfield JF, Allen EE, 2012. De novo metagenomic assembly reveals abundant novel major lineage of Archaea in hypersaline microbial communities. ISME J. 6:81-93.

Negrea S, 1984. [Redescription de Moina salina Daday, 1888 (Cladocera, Moinidae) d'après des exemplaires trouvés en terra typical].[Article in French]. Crustaceana 47:83-97.

Northcote TG, Hall KJ, 1983. Limnological contrasts and anomalies in two adjacent saline lakes. Hydrobiologia 105:179-194.

Ohkouchi N, Nakajima Y, Okada H, Ogawa NO, Suga H, Oguri K, Kitazato H, 2005. Biogeochemical processes in the saline meromictic Lake Kaiike, Japan: implications from molecular isotopic evidences of photosynthetic pigments. Environ. Microbiol. 7:1009-1016.

Oremland RS, Miller LG, 1993. Biogeochemistry of natural gases in three alkaline, permanently stratified (meromictic) lakes. US Geol. Surv. Prof. Pap. 1570:439-452.

Oren A, 2014. The ecology of Dunaliella in high-salt environments. J. Biol. Res.-Thessalon. 21:23.

Oren A, 2016. Life in hypersaline environments, p. 301-339. In: C.J. Hurst (ed.), Their world: A diversity of microbial environments. Springer International Publishing, Cham.

O’Leary JW, Glenn EP, 1994. Global distribution and potential for halophytes, p. 7-17. In: V.R. Squires and A.T. Ayoub (eds.), Halophytes as a resource for livestock and for rehabilitation of degraded land. Kluwer Academic, Dordrecht.

Özcan B, Özcengiz G, Colleri A, Cokmus C, 2007. Diversity of halophilic Archaea from six hypersaline environments in Turkey. J. Microbiol. Biotechnol. 17:985-992.

Pânzaru T, 1974. [Complexul lacustru „Valea Sărată” (Turda). Aspecte morfohidrografice]. [Article in Romanian]. Lucrări Ştiinţifice, seria A, Geografie, Institutul Pedagogic, Oradea 81-98.

Pânzaru T, 1977. [Complexul lacustru de pe masivul de sare de la Ocna-Sibiului (I). Sectoarele lacustre „Incinta Băilor” şi „Parcul Public”].[Article in Romanian]. Lucrări Ştiinţifice, seria A, Geografie, Institutul Pedagogic, Oradea 185-204.

Piernik A, 2005. Vegetation-environment relations on inland saline habitats in Central Poland. Phytocoenologia 35:19-38.

Pişota I, 1960. [Noi date hidrologice asupra lacurilor din Depresiunea Sovatei].[Article in Romanian]. Probleme Geografie 7:179-192.

Podell S, Ugalde JA, Narasingarao P, Banfield JF, Heidelberg KB, Allen EE, 2013. Assembly-driven community genomics of a hypersaline microbial ecosystem. PLoS One 8:e61692.

Pop PG, 2000. [Carpaţii şi Subcarpaţii României].[Book in Romanian].Presa Universitară Clujeană, Cluj-Napoca: 264 pp.

Pop I, Hodişan I, 1980. [Analysis of cormoflora and vegetation in Băile Cojocna (Cluj county)].[Article in Romanian with German Abstract]. Contrib. Botanice 69-87.

Raini JA, 2009. Impact of land use changes on water resources and biodiversity of Lake Nakuru catchment basin, Kenya. Afr. J. Ecol. 47 (suppl.):39-45.

Priscu JC, Axler RP, Carlton RG, Reuter JE, Arneson PA, Goldman CR, 1982. Vertical profiles of primary productivity, biomass and physico-chemical properties in meromictic Big Soda Lake, Nevada, USA. Hydrobiologia 96:113-120.

Sanders C, Huismans R, Van Wees, JD, Andriessen P, 2002. The Neogene history of the Transylvanian basin in relation to its 
surrounding mountains. EGU Stephan Mueller Special Publication, Series 3:121-133.

Santamaría L, 2002. Why are most aquatic plants widely distributed? Dispersal, clonal growth and small-scale heterogeneity in a stressful environment. Acta Oecol. 23:137-154.

Schär C, Vidale PL, Lüthi D, Frei C, Häberli C, Liniger MA, Appenzeller C, 2004. The role of increasing temperature variability in European summer heatwaves. Nature 427:332-336.

Shadkam S, Ludwig F, van Vliet MT, Pastor A, Kabat P, 2016. Preserving the world second largest hypersaline lake under future irrigation and climate change. Sci. Total Environ. 559:317-325.

Somogyi B, Vörös L, Pálffy K, Székely G, Bartha C, Keresztes, ZG, 2014. Picophytoplankton predominance in hypersaline lakes (Transylvanian Basin, Romania). Extremophiles 18:1075-1084.

Sonnenfeld P, Hudec PP, 1980. Heliothermal lakes. In: A. Nissenbaum (Ed.), Hypersaline brines and evaporitic environments. Proceedings of the Bat Sheva Seminar on Saline Lakes and Natural Brines. Dev. Sedimentol. 28:93-100.

Sorokin DY, Banciu HL, Muyzer G, 2015. Functional microbiology of soda lakes. Curr. Opin. Microbiol. 25:88-96.

Sorokin DY, Foti M, Pinkart HC, Muyzer G, 2007. Sulfur-oxidizing bacteria in Soap Lake (Washington State), a meromictic, haloalkaline lake with an unprecedented high sulfide content. Appl. Environ. Microbiol. 73:451-455.

Sorokin DY, Kublanov IV, Yakimov MM, Rijpstra WIC, Damsté JSS, 2016. Halanaeroarchaeum sulfurireducens gen. nov., sp. nov., the first obligately anaerobic sulfur-respiring haloarchaeon, isolated from a hypersaline lake. Int J Syst. Evol. Microbiol. 66:2377-2381.

Sorokin DY, Messina E, Smedile F, Roman P, Damsté JSS, Ciordia S, Mena MC, Ferrer M, Golyshin PN, Kublanov IV, Samarov NI, Toshchakov SV, La Cono V, Yakimov MM, 2017. Discovery of anaerobic lithoheterotrophic haloarchaea, ubiquitous in hypersaline habitats. ISME J. 11:1245-1260.

Spiridon L, Popescu G, Matei M, 1984. [Halophyte vegetation of the lakes in Ocna Sibiului].[Article in Romanian]. Acta Botanica Horti Bucurestiensis 1983-1984:201-210.

Stevanović ZD, Aćić S, Luković M, Zlatković I, Vasin J, Topisirović G, Šilc U, 2016. Classification of continental halophytic grassland vegetation of Southeastern Europe. Phytocoenologia 46:317-331.

Swan BK, Ehrhardt CJ, Reifel KM, Moreno LI, Valentine DL, 2010. Archaeal and bacterial communities respond differently to environmental gradients in anoxic sediments of a California hypersaline lake, the Salton Sea. Appl. Environ. Microbiol. 76:757-768.
Şerban G, Alexe M, Touchart L, 2005. [L'evolution du modele lacustre et la salinite des lacs de Cojocna (Plaine de Transylvanie, Roumanie)].[Article in French]. Bull. Ass. Geogr. Fr. II 2:234-245.

Todor I, 1947. [La flore et la végétation des Bains Salés (Băile Sărate) de Turda (Transylvanie, Roumanie)].[Article in Romanian with French abstract]. Bul. Grad. Bot. Muz. Bot. Univ. Cluj. 27:1-64.

Talbot MR, 1988. The origins of lacustrine oil source rocks: evidence from the lakes of tropical Africa. Geol. Soc. Spec. Publ. 40:29-43.

Touchart L, 2002. [Limnologie physique et dynamique. Une géographie des lacs et des étangs].[Book in French]. Edit. de L'Harmattan, Paris: 395 pp.

Triantaphyllidis G, Abatzopoulos T, Sorgeloos P, 1998. Review of the biogeography of the genus Artemia (Crustacea, Anostraca). J. Biogeogr. 25:213-226.

Wu QL, Chatzinotas, A, Wang, J, Boenigk J, 2009. Genetic diversity of eukaryotic plankton assemblages in eastern Tibetan lakes differing by their salinity and altitude. Microb. Ecol. 58:569-581.

Walker KF, 1974. The stability of meromictic lakes in central Washington. Limnol. Oceanogr. 19:209-222.

Williams WD, 1998. Management of inland saline waters. Guidelines of lake management. 6. ILEC/UNEP, Kusatsu: 108 pp.

Yau S, Lauro FM, Williams TJ, DeMaere MZ, Brown MV, Rich J, Gibson JAE, Cavicchioli R, 2013. Metagenomic insights into strategies of carbon conservation and unusual sulfur biogeochemistry in a hypersaline Antarctic lake. ISME J. 7:1944-1961.

Zachara JM, Moran JJ, Resch CT, Lindemann SR, Felmy AR, Bowden ME, Cory AB, Fredrickson JK, 2016. Geo-and biogeochemical processes in a heliothermal hypersaline lake. Geochim. Cosmochim. Acta 181:144-163.

Zadereev ES, Gulati RD, Camacho A, 2017. Biological and ecological features, trophic structure and energy flow in meromictic lakes, p. 61-86. In: R.D. Gulati, E.S. Zadereev and A.G. Degermendzhi (eds.), Ecology of meromictic lakes. Springer International Publishing, Switzerland.

Zhaxybayeva O, Stepanauskas R, Mohan NR, Papke RT, 2013. Cell sorting analysis of geographically separated hypersaline environments. Extremophiles 17:265-275.

Ziegler G, 1898. [An den Herausgeber des Prometheus].[Article in German]. Prometheus 9:79. Comments in: O. Lang, 1898. [Absonderliche Temperaturverhältnisse in einem Solbehältern].[Article in German]. Prometheus 9:325. 